\title{
Ontogeny, morphology and pedicle attachment of stenothecoids from the middle Cambrian of North Greenland (Laurentia)
}

John S. PeEL

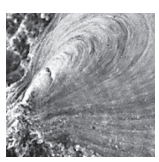

The bivalved calcareous shells of stenothecoids are generally both inequilateral and inequivalve. They occur in lower and middle Cambrian strata from Laurentia, Siberia, Kazakhstan and China, but their affinities are unresolved. Contemporary workers favour assignment as a separate class of Mollusca or within the stem-group of Brachiopoda. The latter is supported by the present description of pedicle attachment in stenothecoids from the Henson Gletscher Formation (Miaolingian Series, Wuliuan Stage) of North Greenland. Described material from Greenland is mainly preserved as internal moulds showing a high degree of variability that frustrates comparisons with assemblages from other localities and horizons, but provides insight into central features of stenothecoid morphology. Curvature of individual valves is shown to be an unreliable morphological indicator in the North Greenland sample. Early juveniles of Stenothecoides are described confirming the development of a transverse tooth in the interior of the ventral valve throughout ontogeny. A pitted structure near the apex of juvenile internal moulds is interpreted as the scar of a fibrous pedicle attaching the ventral valve to the substrate. Frondose impressions on the shell interior, previously considered to be characteristic of Bagenovia, are described in Stenothecoides. Multiple median scars on the dorsal valve characteristic of Stenothecella (Cambrian Stage 4) are also described in the Wuliuan material from North Greenland. New species: Stenothecoides terraglaciei sp. nov. Key words: Cambrian, Wuliuan Stage, Stenothecoida, ontogeny, pedicle, North Greenland, Laurentia.

PeEL, J.S. 2021. Ontogeny, morphology and pedicle attachment of stenothecoids from the middle Cambrian of North Greenland (Laurentia). Bulletin of Geosciences 96(4), 381-399 (9 figures). Czech Geological Survey, Prague. ISSN 1214-1119. Manuscript received July 11, 2021; accepted in revised form August 27, 2021; published online September 26, 2021; issued October 1, 2021.

John S. Peel, Department of Earth Sciences (Palaeobiology), Uppsala University, Uppsala, Sweden; john.peel@pal.uu.se

Brachiopods are the most common and diverse bivalved fossils in the Cambrian, but the adaptation to enclose the soft parts within two articulating shells is widespread in the Cambrian biota. Amongst arthropods, bradoriids and phosphatocopines are also diverse and widely distributed (Hinz-Schallreuter 1993, Williams et al. 2007, Zhang 2007, Maas et al. 2003, McMenamin 2020), but a variety of other bivalved or pseudo-bivalved arthropods is known, mainly through occurrences in Lagerstätten such as the Burgess Shale and Chengjiang biotas (Briggs et al. 1994, Hou et al. 2017). Members of the molluscan Class Bivalvia are few in the Cambrian, but one of these, Pojetaia Jell, 1980, is widely distributed in the early and middle Cambrian (Elicki \& Gürsu 2009, Vendrasco et al. 2011a).

Shell symmetry in the problematic inequivalved bivalves Apistoconcha Conway Morris in Bengtson et al., 1990 and Aroonia Bengtson in Bengtson et al., 1990, originally described from the early Cambrian of Australia (Bengtson et al. 1990), is similar to that of brachiopods. Parkhaev (1998) placed Apistoconcha within a new class,
Siphonoconcha, of uncertain position. Both genera may be stem group brachiopods (Bengtson 2004, Li et al. 2014).

The calcareous shells of most members of the Class Stenothecoida Yochelson, 1968 (= Phylum Stenothecata Rozov, 1984) differ from brachiopods (usually inequivalve but equilateral) and Bivalvia (usually equivalve but inequilateral) in being neither equivalve nor equilateral (Yochelson 1969, Rozov 1984; Fig. 1), but their systematic position is equivocal. Laurentian stenothecoids are generally referred just to Stenothecoides Resser, 1938 (Rasetti 1954, 1957; Robison 1964; Yochelson 1969; Peel 1988; Johnston et al. 2017; Johnston 2019; Fig. 1A, H), but a number of other genera and numerous species have been described from the Cambrian of Siberia and eastern Asia (Horný 1957; Sytchev 1960; Aksarina 1968; Yochelson 1969; Koneva 1976, 1979a, b; Pelman 1976, 1985; Aksarina \& Pelman 1978; Voronin et al. 1982; Rozov 1984; Esakova \& Zhegallo 1996; Yu 1996). Stenothecoids are distributed through Cambrian Series 2 and the Miaolingian (Rozanov \& Zhuravlev 1992). Stenothecoides groenlandica Peel, 1988, from the late Miaolingian Series, 
Guzhangian Stage, of North Greenland appears to be the youngest recorded occurrence (Peel 1988; Fig. 1A, H).

Stenothecoides was proposed by Resser (1938) for Stenotheca elongata Walcott, 1884 from the middle Cambrian of the Eureka District of Nevada (Walcott 1884). In addition to the type species, Resser (1938) included three new early Cambrian species within the genus: Stenothecoides labradorica from the Forteau Formation of Newfoundland; Stenothecoides troyensis from New York State (a synonym of S. labradorica according to
Rasetti 1954); and Stenothecoides poulseni from the Ella Island Formation of North-East Greenland (Poulsen 1932, Skovsted 2006). Resser (1938) interpreted Stenothecoides as an elongate univalved crustacean related to Stenotheca Salter in Hicks, 1872, although the latter is currently interpreted as a helcionelloid mollusc (Bouchet et al. 2017, Peel 2021a). However, Poulsen (1932) had interpreted the Greenland specimens subsequently named in his honour by Resser (1938) as Bivalvia, an affinity supported by Robison (1964). Radugin (1937) assigned related material

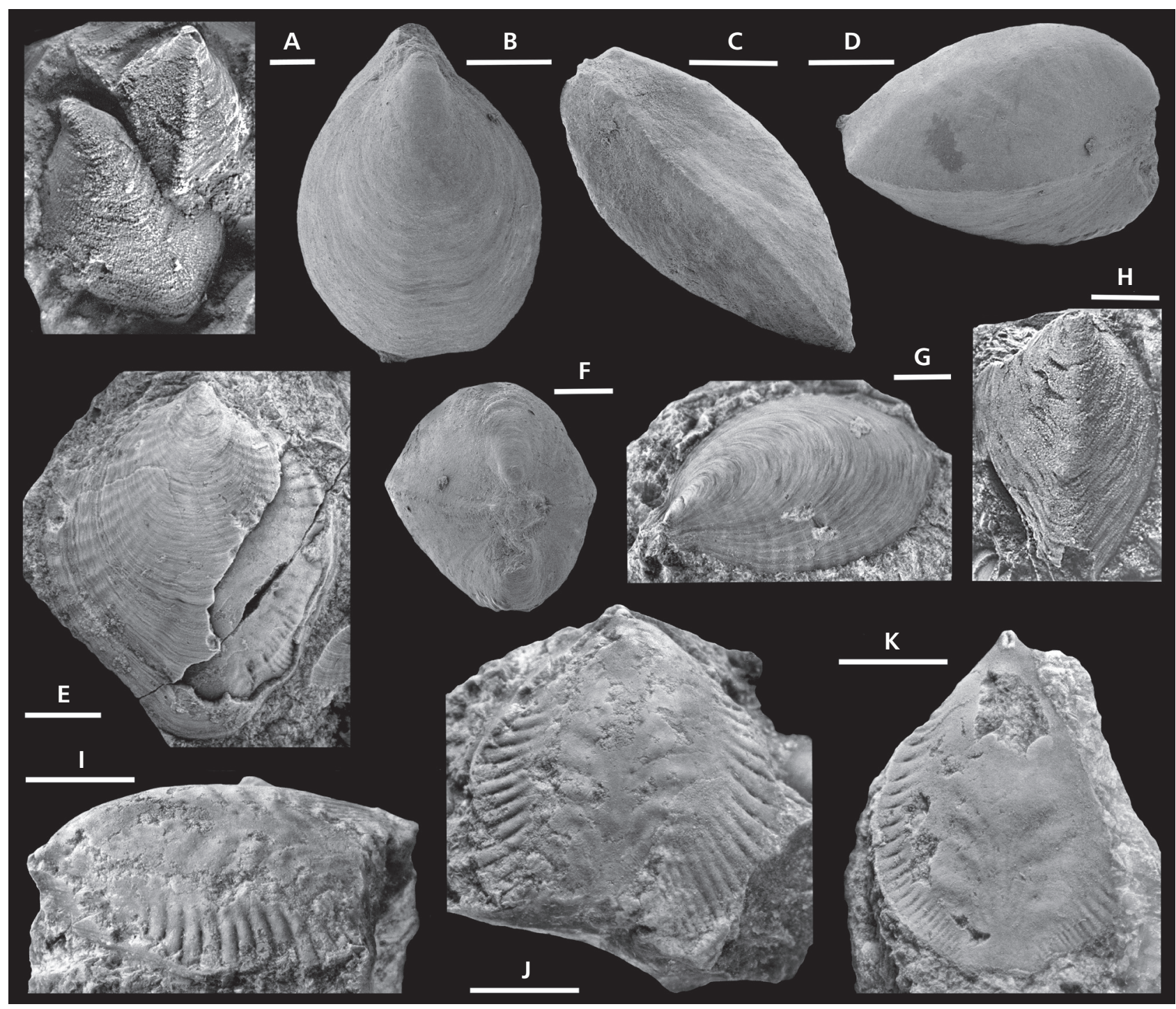

Figure 1. Stenothecoids from the Cambrian of Greenland and Siberia. • A, H - Stenothecoides groenlandica Peel, 1988, Cambrian (Miaolingian Series, Guzhangian Stage), Holm Dal Formation, western Peary Land, North Greenland; A - MGUH 18674 and MGUH 18675 from GGU sample 225552; H - MGUH 18671 from GGU sample 225552, holotype. • B, D, F, G, K - Bagenovia procera Koneva, 1976, lower Cambrian (Lenian Regional Stage) Agyrek Mountain, central Kazakhstan; B, D, F - articulated topotype specimen (KIS collection 2048) with broken apex of dorsal valve, identified by Svetlana Koneva, in ventral, lateral and anterior views; G - KIS 8/2048, holotype, in postero-lateral view; K - internal mould, KIS 13/2048. • C - Stenothecoides bellus Koneva, 1979, KIS 54/2048, holotype in lateral view, lower Cambrian (Lenian Regional Stage), Kazakhstan. • E, I, J - Bagenovia kazakhstanica Koneva, 1976, lower Cambrian (Lenian Regional Stage), Agyrek Mountain, central Kazakhstan; E - KIS 1/2048, holotype, partly exfoliated to show internal mould at right; I, J - KIS 24/2048 internal mould in oblique lateral and plan views. Scale bars: $4 \mathrm{~mm}$ (E), $3 \mathrm{~mm}(\mathrm{I}-\mathrm{K}), 2 \mathrm{~mm}(\mathrm{H}), 1 \mathrm{~mm}$ (A), $400 \mu \mathrm{m}$ (B-D, F, G). 
A

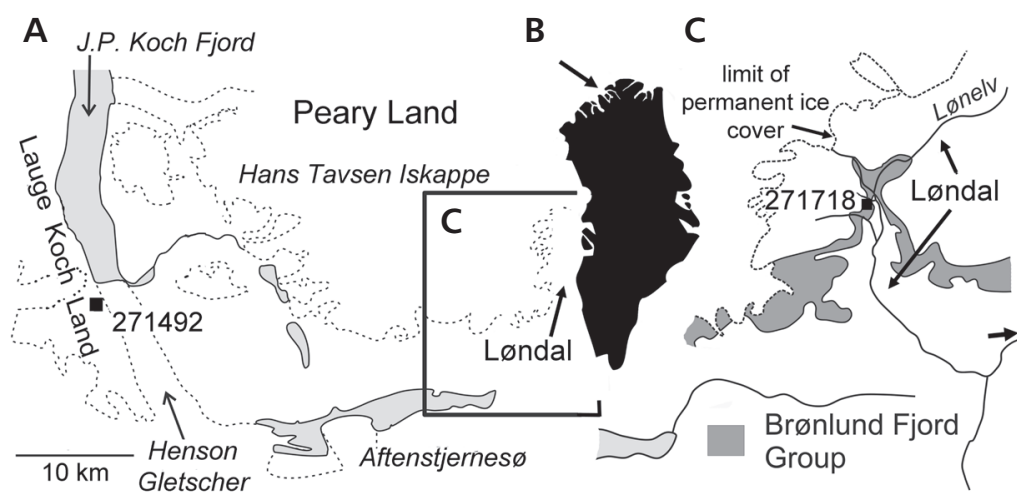

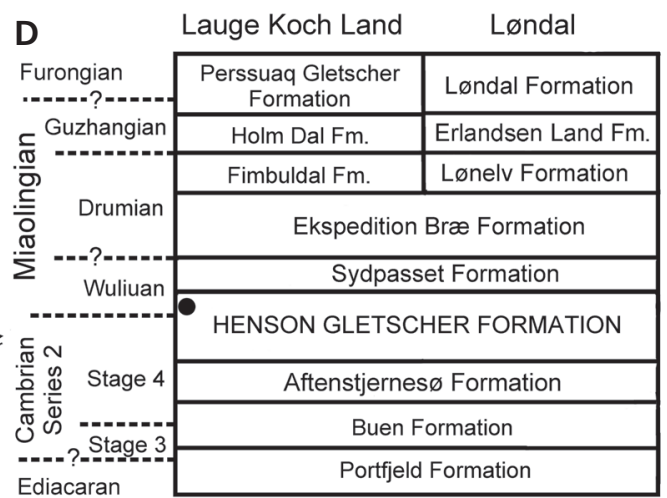

Figure 2. Locality and geological information. • A - Lauge Koch Land - Løndal region of North Greenland showing collection site of GGU sample 271492. • B - Greenland, with arrow indicating location of A. • C - Løndal region of western Peary Land (see inset in A) showing collection locality for GGU sample 271718. • D - Cambrian stratigraphic nomenclature of the Lauge Koch Land - Løndal region showing derivation of GGU samples from Henson Gletscher Formation (black dot).

from Siberia, later described by Horný (1957), to the Brachiopoda. Horný (1957) proposed two new genera, Bagenovia (Fig. 1E, I-K) and Cambridium, which he interpreted tentatively as amphineurans; Bagenovia Radugin, 1937 is a nomen nudum. Articulated, bivalved, specimens of $B a$ genovia sajanica Horný, 1957 were described by Sytchev (1960) who interpreted Cambridium and Bagenovia as dysodont Bivalvia. Aksarina (1968) proposed a new Class Probivalvia (Mollusca, Conchifera) on the basis of lower Cambrian material from the Altai-Sayan region of Siberia.

Yochelson (1968) introduced the name Stenothecoida in a published abstract and this was fully described as a new class of molluscs by Yochelson (1969). Despite Yochelson's statement (1969, p. 59) that his 1968 abstract should not constitute appropriate description, Stenothecoida Yochelson, 1968 has been accepted generally by subsequent workers in preference to Probivalvia Aksarina, 1968 (Koneva 1976, Pelman 1976, Pojeta \& Runnegar 1976, Aksarina \& Pelman 1978, Rozov 1984). Rozov (1984) proposed a new Phylum Stenothecata, as noted by Parkhaev (1998), Kouchinsky (2000) and Zhuravlev (2015), while Pelman (1985) placed Class Stenothecoida as incertae sedis. Kouchinsky (2000) speculated that stenothecoids may have been derived from a halkieriid-like ancestor through loss of the numerous sclerites separating the large anterior and posterior shells. Johnston et al. (2017) and Johnston (2019) suggested that the affinity of Stenothecoida lay with brachiopods rather than molluscs. Ponder et al. (2020) considered stenothecoids to be located outside of Mollusca.

This paper describes stenothecoids from the Henson Gletscher Formation (Cambrian, Miaolingian Series, Wuliuan Stage) of North Greenland with a focus on preservation, early ontogeny and morphology. Discrimination of individual valves as ventral or dorsal on the basis of their curvature is shown to be an unreliable character in available specimens and must be supported by other morphological features, such as the relative morphology of their posterior apices. The frondose impression of soft parts on the valve interior in the median area, considered to be diagnostic of Bagenovia by Koneva (1976), is described in Stenothecoides. Juvenile stenothecoids are recognized on the basis of the prominent tooth on the interior of the ventral valve. They also preserve an unusual structure at the posterior margin interpreted as a pedicle attachment scar.

\section{Material and methods}

The Henson Gletscher Formation (Fig. 2D) forms part of a prograding complex of shelf carbonates and siliciclastic sediments that accumulated on the present day southern margin of the transarctic Franklinian Basin (Higgins et al. 1991, Ineson \& Peel 1997, Geyer \& Peel 2011, Peel et al. 2016). The formation is mainly composed of dark, recessive, shaly-weathering, bituminous and cherty limestones, dolostones and mudstones, with a middle member of pale fine-grained sandstones. Thin carbonate debris flows occur sporadically. The Henson Gletscher Formation is $62 \mathrm{~m}$ thick at its type locality in southern Lauge Koch Land, from which GGU sample 271492 was collected (Fig. 2A), but thins to $47 \mathrm{~m}$ in Løndal, to the east, from where GGU sample 271718 was collected (Fig. 2A, C).

Fossil assemblages from the Henson Gletscher Formation in southern Lauge Koch Land and south-western Peary Land range in age from Cambrian Series 2 (Stage 4, Dyeran Stage of North American usage) to the Miaolingian Series (Wuliuan Stage; Ptychagnostus gibbus Biozone; Topazian of North American usage), but Drumian strata occur along the northern coast of North Greenland (Higgins et al. 1991, Robison 1994, Blaker \& Peel 1997, Ineson \& Peel 1997, Geyer \& Peel 2011; Fig. 2). The trilobite faunas have a dominantly Laurentian 


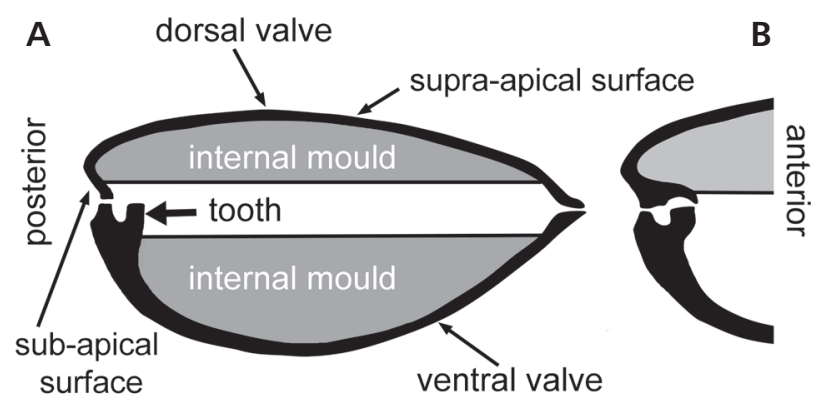

C
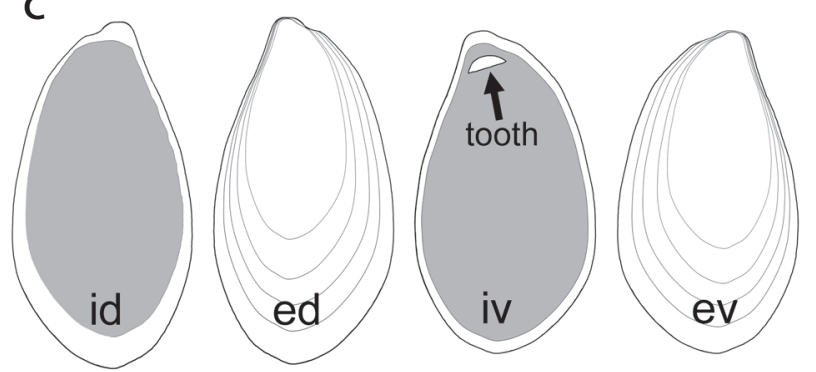

dorsal valve

D
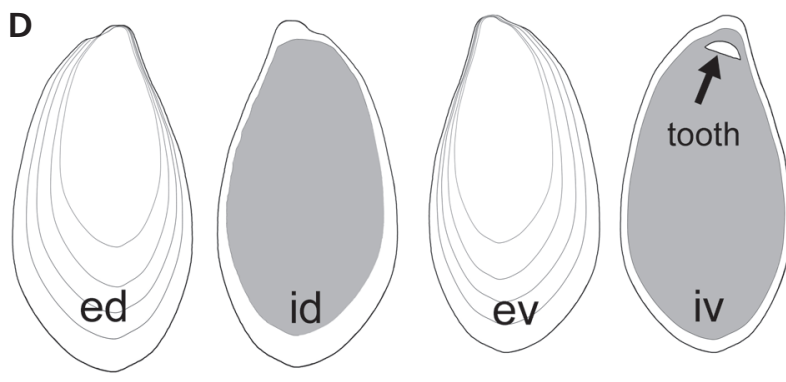

Figure 3. Morphology of Stenothecoides. A - schematic longitudinal section showing distinction between the partial internal moulds of the dorsal and ventral valves, and restoration of tooth and posterior margin of valves. $\cdot \mathrm{B}$ - alternative restoration of tooth and posterior margin of valves with socket in dorsal valve corresponding to tooth in ventral valve. $\cdot \mathrm{C}$ - schematic drawings of individual valves in internal and external views based on clockwise curvature of the internal surface (iv) of the tooth-bearing ventral valve. $\cdot \mathrm{D}$ - schematic drawings of individual valves in internal and external views based on anti-clockwise curvature of the internal surface (iv) of the tooth-bearing ventral valve. Abbreviations: ed - external view of dorsal valve; ev - external view of ventral valve; id - internal view of dorsal valve; iv - internal view of ventral valve, with tooth.

character but include taxa important for international correlation with Siberia, the Altai Sayan fold belt and South China (Blaker \& Peel 1997, Geyer \& Peel 2011).

GGU sample 271492 was collected by J.S. Peel on 25 June 1978 from limestone filling scours on the top of a $1 \mathrm{~m}$ thick carbonate mass flow deposit, about $5 \mathrm{~m}$ below the top of the Henson Gletscher Formation in its type section ( $62 \mathrm{~m}$ thick) in southern Lauge Koch Land $\left(82^{\circ}\right.$ $10^{\prime} \mathrm{N}, 40^{\circ} 24^{\prime} \mathrm{W}$ ); Ineson \& Peel (1997, fig. 23, section B; fig. 31), Geyer \& Peel (2011, fig. 3).

GGU sample 271718 was collected by J.S. Peel on 15 July 1978 from thin-bedded, phosphatized, dark dolo- mitic limestone occurring about $1 \mathrm{~m}$ below the top of the formation on the west side of Løndal (Fig. 1); Clausen \& Peel (2012, fig. 1).

Methods. - Specimens were hand-picked from sieved residues of limestone routinely dissolved in $10 \%$ acetic acid prior to microphotography using a Lumenera Infinity X32 digital camera attached to a Wild binocular microscope, or imaging by scanning electron microscopy. Images were assembled in Adobe Photoshop CS4; some were stacked using Helicon Focus.

Institutional abbreviations. - GGU - Grønlands Geologiske Undersøgelse (Geological Survey of Greenland), Copenhagen, Denmark, now the Geological Survey of Denmark and Greenland (GEUS); MGUH - Natural History Museum of Denmark, Copenhagen, Denmark; KIS - K.I. Satpayev Institute of Geological Sciences. Kazakh Academy of Sciences, Alma Ata, Kazakhstan; PMU - palaeontological type collection of the Museum of Evolution, Uppsala University, Uppsala, Sweden.

\section{Terminology and orientation}

Rozov (1984) and Pelman (1985) proposed detailed terminology and nomenclature for the measurement of stenothecoid shells. Yochelson (1969) followed earlier workers and regarded the apex of each valve as anterior. However, in accordance with the direction of accretion of the growing shell, the apical end of each valve is interpreted herein as posterior, as in brachiopods, while the abapical margin end is anterior (Fig. 3A). Yochelson (1969) considered the more inflated of the two conjoined valves in two species of Stenothecoides to be ventral and on this basis noted that the shell with conjoined valves was curved in an anticlockwise direction from the apex to the distal margin when viewed in dorsal aspect (ed in Fig. 3D). Thus, isolated ventral and dorsal valves are curved in opposite directions when viewed from their respective external surface (compare ed and ev in Fig. 3D). Peel (1988) applied this interpretation with reservation when interpreting isolated valves in a small collection from the Holm Dal Formation (Guzhangian Stage) of western Peary Land, noting that ventral and dorsal in the usage of Yochelson (1969) corresponded to left and right in the terminology of Koneva (1976).

The prominent adapical tooth on the interior surface of valves from North Greenland, here interpreted as ventral (Fig. 3A), provides a unique point of reference for the interpretation of the curvature of disarticulated valves. Such a tooth was first described by Robison (1964) in silicified specimens of Stenothecoides elongata from the Wheeler Shale and Marjum formations of Utah. It is 


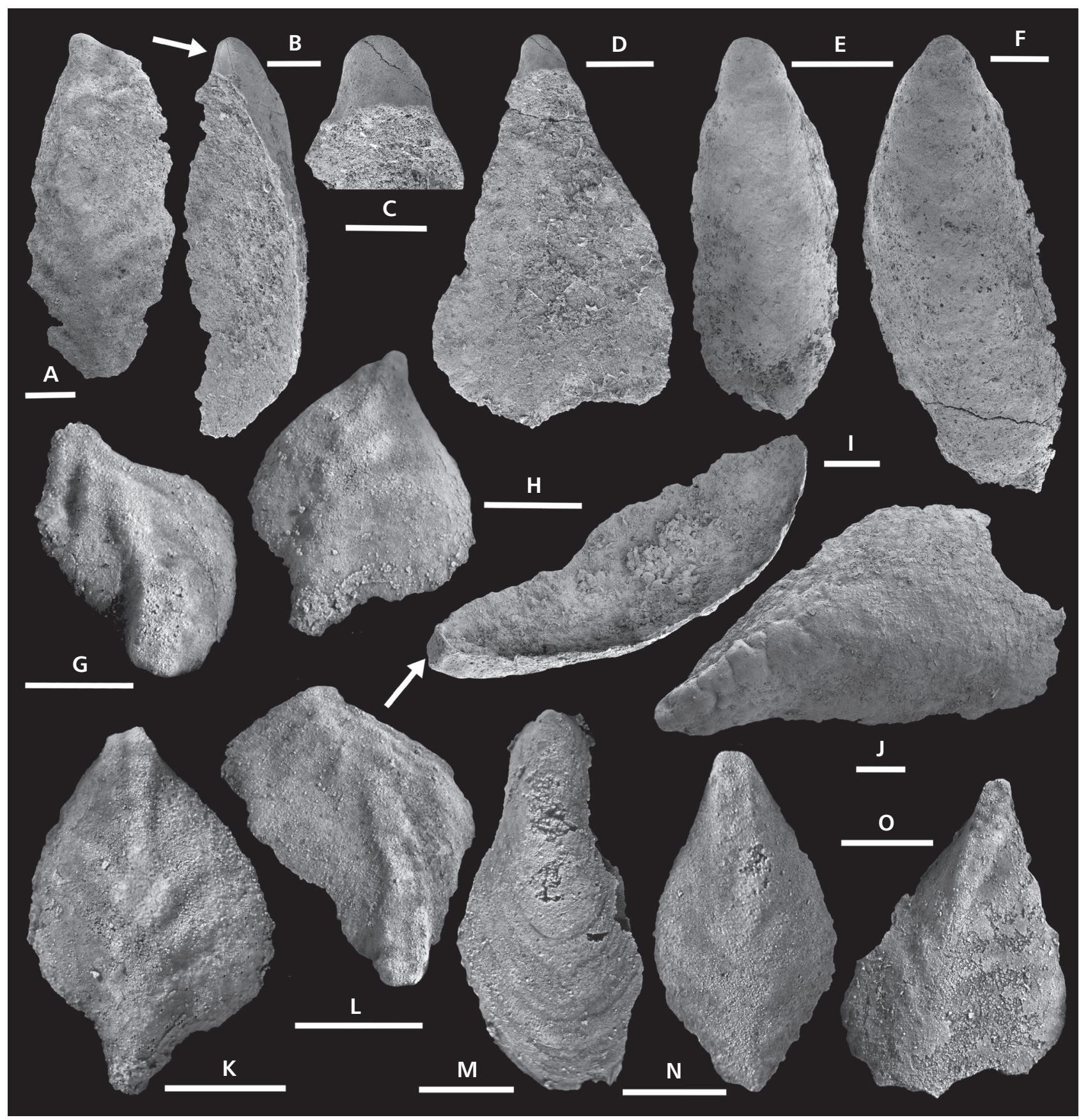

Figure 4. Stenothecoides terraglaciei $\mathrm{n}$. sp. Internal moulds (except M). GGU sample 271718, Henson Gletscher Formation, Wuliuan Stage, Løndal, Peary Land. A - PMU 38304, dorsal valve; B - PMU 38305, dorsal valve in oblique lateral view, arrow indicates sub-apical surface; C, D - PMU 38306, dorsal valve, with detail of sub-apical surface in C; E - PMU 38307, ventral valve; F - PMU 38308, dorsal valve; G - PMU 38309, ventral valve in oblique posterior view; H, K - PMU 38310, dorsal valve in oblique anterior $(\mathrm{H})$ and plan $(\mathrm{K})$ views; I -PMU 38311, ventral valve showing truncated sub-apical surface, arrow; J - PMU 38312, dorsal valve; L - PMU 38313, dorsal(?) valve in oblique posterior view showing prominent median carina; M - PMU 38314, fragment of external surface of ventral valve showing comarginal growth ornamentation; note that both lateral margins are broken away; N - PMU 38315, dorsal valve; O - PMU 38316, dorsal valve. Scale bars: 1 mm (G, H, K-O), $500 \mu \mathrm{m}$ (A, B, D, I, J), $300 \mu \mathrm{m}$ (C), $200 \mu \mathrm{m}$ (E, F).

evident from examination of the Greenland specimens that the growing ventral valve may curve in either a clockwise or an anticlockwise direction (compare Fig. 3C and 3D), while some specimens are essentially equilateral. Thus, in articulated specimens or valves known only from their exterior surface, curvature alone is not a reliable character on which to distinguish dorsal and ventral valves. Additional support should be sought from the relative degree of inflation of the valves and the nature of the apices (Fig. $3 \mathrm{~A}$, and discussion of preservation, below). 


\section{Preservation}

Acid residues of GGU sample 271492 have yielded only phosphatized juvenile specimens of Stenothecoides, although carbonate internal moulds of specimens up to $5 \mathrm{~mm}$ in length occur sparingly in hand specimens of untreated limestone. GGU sample 271718 yielded abundant stenothecoids that dominantly are preserved as phosphatized internal moulds ranging in length from juveniles $(300 \mu \mathrm{m})$ to specimens more than $5 \mathrm{~mm}$ (Fig. 4); still larger specimens occur on unprepared bedding surfaces. Juveniles apart, small internal moulds are often strongly elongated, almost parallel-sided (Fig. 4E, F). The largest specimens often increase in width distally and may be diamond or leaf shaped (Fig. 4N, O). However, the preserved shape of internal moulds is controlled to a large degree by the extent of phosphatization. Typically, the internal moulds from GGU sample 271718 have a well preserved apex and median area, but the lateral margins are ragged, clearly indicating that the phosphatization of the internal moulds was usually concentrated in the apical area and along the crest of the original shell. The phosphatized moulds thin out laterally and distally to a feather edge within the margins of the original shell, and do not extend to, or around, the margin (Fig. 4B, I). Thus, in most cases, the shape of the internal mould in GGU sample 271718 does not accurately reflect the shape of the valve at the plane of commissure.

Less frequently, partly exfoliated specimens retain patches of thick shell attached to the internal mould (Fig. $5 \mathrm{G}-\mathrm{J}, \mathrm{L}-\mathrm{O})$. Most of these display a prominent tooth within the shell interior at its apical extremity (Fig. 5G, arrow) and are interpreted as the ventral valve (Fig. 3A). The tooth forms a transverse bar that is bounded laterally and adapically by a narrow and shallow channel (Fig. 5J), which may be separated from the deeper shell interior to the anterior of the tooth by a narrow lip (Fig. 5L). The adapical portion of the channel is usually crescentic or triangular in shape, its length being greater than the transverse width of the lateral channels (Fig. 5G). Except in the smallest juvenile ventral valves (Figs 5A-F, K; 6; discussed below), the prominent transverse tooth is not recognized on the surface of available internal moulds as preserved (Fig. 4). However, the presence of a tooth can be inferred in some internal moulds from the shape of the apical termination of the mould.

Two kinds of apical termination of internal moulds are recognized, permitting identification of the ventral and dorsal valves. In the first, the sub-apical surface is truncated and only slightly overhanging (Fig. 4I, arrow). The truncated surface was formed against the abapical surface of the transverse tooth (Figs 3A; 5G, J, L). The restriction of phosphatization to the median area of the valve (Fig. 5G, H), away from the shell margins, has prevented moulding of the shallow lateral and adapical channel. Thus, internal moulds with a truncated apex are interpreted as ventral valves (Figs 3A, 4I, 5G). In the second type, the rounded apex is sub-conical in form, strongly protruding, with a well-developed sub-apical surface (Fig. 4B, arrow). This internal mould is interpreted as representing the dorsal valve, which may overhang the ventral valve at the sub-apical margin (Fig. 3A). There is no indication of the presence of a transverse tooth and this is considered to be absent from the dorsal valve. It is possible, however, that similarly shaped internal moulds may be produced within dorsal valves in which a socket corresponging to the ventral tooth is developed (Fig. 3B).

\section{Systematic palaeontology}

This published work and the nomenclatural acts it contains have been registered in ZooBank http://zoobank.org/ References/701AF529-64BB-4D0B-B961-9611A11CE73E

\section{Phylum incertae sedis \\ Class Stenothecoida Yochelson, 1968}

Discussion. - While the prominent radial corrugation on the external surface of the type (Bagenovia sajanica) and some other species of Bagenovia (Fig. 1E) delimits the genus from Cambridium and Stenothecoides, in which the external ornamentation is restricted to comarginal growth lines, the separation of the last two genera from each other is less satisfactory. Horný (1957) commented on the presence of a flat median keel (carina) in Stenothecoides and deep grooves and ridges in a restricted zone perpendicular to the lateral margins on the internal mould, the latter with reference to material described by Rasetti (1954) from British Columbia. Additionally, Koneva (1979a) commented that Cambridium is isometric, whereas Stenothecoides is elongate. Neither author reported the internal tooth first described in Stenothecoides by Robison (1964). All three genera, however, show considerable variation in shell form and some specimens assigned to Bagenovia procera by Svetlana Koneva in the original material of Koneva (1976) lack the radial ornamentation otherwise characteristic of the genus (Fig. 1B, D, F). Horný (1957) and Koneva (1979a, b) described Cambridium and Stenothecoides from Cambrian Series 2, but only Stenothecoides is reported from the Miaolingian Series (Rasetti 1954, 1957; Robison 1964; Peel 1988).

The variable preservation of the material at hand frustrates simple assignment to Cambridium or Stenothecoides. Rare internal moulds in limestone from GGU sample 271492 are elongate with prominent lateral corrugation on the internal mould (Fig. 7) and are readily 


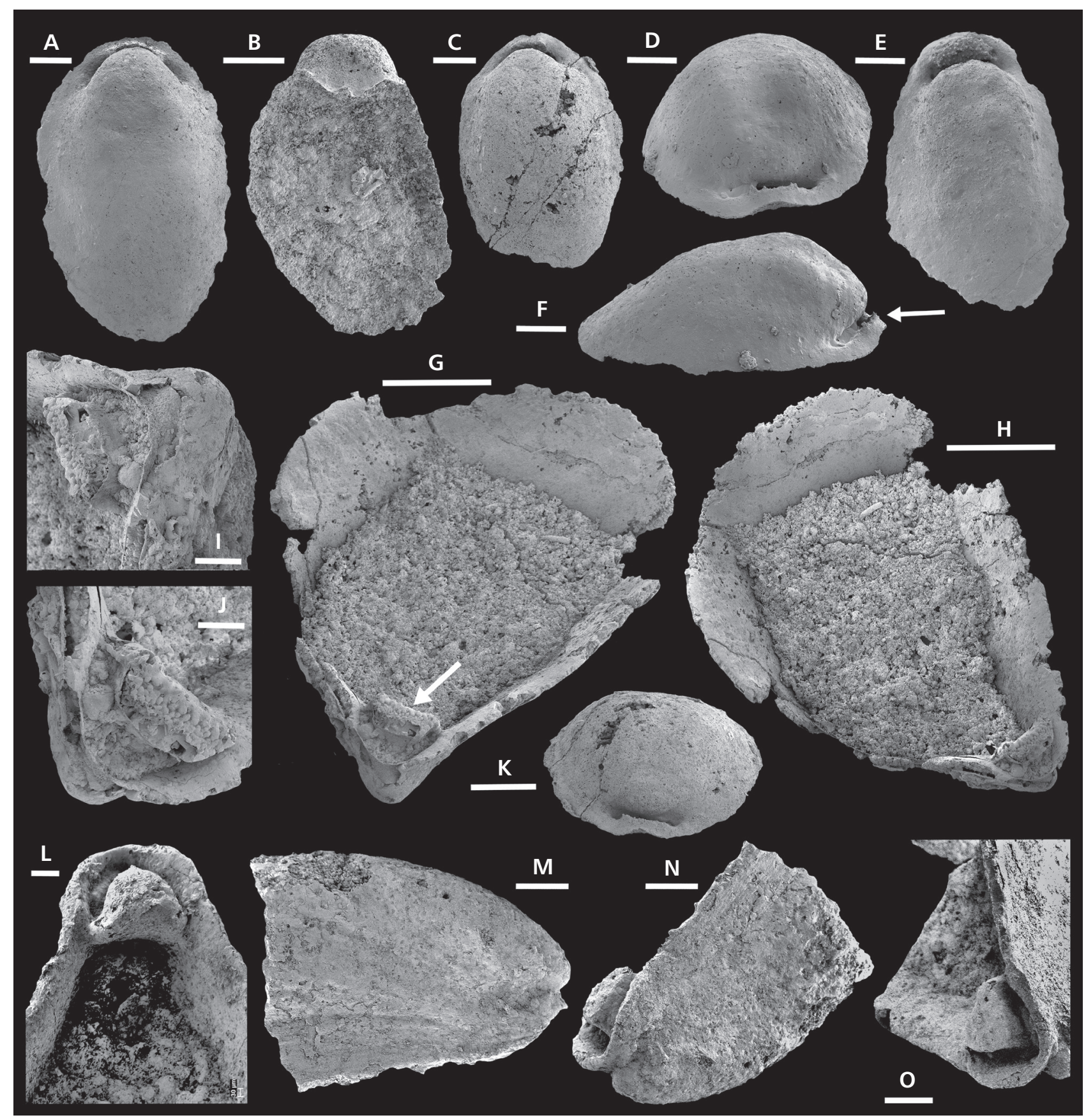

Figure 5. Stenothecoides terraglaciei sp. nov. Henson Gletscher Formation, Cambrian (Miaolingian Series, Wuliuan Stage). GGU sample 271492 (A-F, K), Lauge Koch Land; GGU sample 271718 (G-J, L-O), Løndal. A - PMU 38317, internal mould of juvenile ventral valve; B - PMU 38318, internal mould of ventral valve showing overhanging surface of impression of transverse tooth; C, K - PMU 38319, internal mould of juvenile ventral valve in plan and oblique posterior views; D, F - PMU 38320, internal mould of ventral valve showing slot corresponding to transverse tooth (arrow in F); E - PMU 38321, internal mould of juvenile ventral valve; G-J - PMU 38322, holotype, internal views of partly sediment filled ventral valve $(\mathrm{G}, \mathrm{H})$ with transverse tooth (arrow in $\mathrm{G}$ ) and details of tooth and sub-apical surface (I, J); L-O - PMU 38323, ventral valve, internal view showing tooth and posterior, comarginal channel $(\mathrm{L})$, lateral and oblique lateral views showing sub-apical emargination $(\mathrm{M}, \mathrm{N})$, oblique posterior view showing emargination and tooth (O). Scale bars: $1 \mathrm{~mm}(\mathrm{G}, \mathrm{H}), 200 \mu \mathrm{m}(\mathrm{I}, \mathrm{J}, \mathrm{M}-\mathrm{O}), 100 \mu \mathrm{m}(\mathrm{A}-\mathrm{F}, \mathrm{K}, \mathrm{L})$

assigned to Stenothecoides by comparison with material described from the upper Mount Whyte Formation (Wuliuan Stage) of British Columbia by Rasetti (1954) and Yochelson (1969). Specimens from GGU sample
271718 are dominantly phosphatized internal moulds that lack the lateral corrugation (Fig. 4). They are associated with partly exfoliated specimens with a prominent tooth in the ventral valves, as in elongate silicified specimens from 
Utah assigned to Stenothecoides elongata by Robison (1964), but which also lack marginal corrugation on the smooth inner shell surface (Fig. 5G, H). The presence of a tooth socket opposing the tooth, described by Robison (1964) in disarticulated silicified valves, has not been demonstrated in the Greenland material. The internal moulds from GGU sample 271718 often show a frondose medial pattern of broad ridges and shallow channels (Fig. 4A, K, O) that Koneva (1976) considered characteristic of Bagenovia (Fig.1I-K). However, the overall more elongated form of these specimens from GGU sample 271718 and their lack of radial ridges on the exterior motivate their assignment to Stenothecoides.

\section{Genus Stenothecoides Resser, 1938}

Type species. - Stenotheca elongata Walcott, 1884, USNM locality 55b, Prospect Peak, Eureka District, Nevada, Miaolingian Series, late Wuliuan Stage, BathyuriscusElrathina Biozone (Rasetti 1954, Palmer 1954).

\section{Stenothecoides terraglaciei sp. nov.}

Figures 4-6

Holotype. - PMU 38322 from GGU sample 271718.

Type horizon and locality. - Henson Gletscher Formation, Løndal, Peary Land, North Greenland. Cambrian, Miaolingian Series, Wuliuan Stage, Ptychagnostus gibbus Biozone.

Additional material. - PMU 38304-38316, 38323 from the same locality and horizon as the holotype. PMU 38317-38321, 38327 are juvenile internal moulds from GGU sample 271492 that are indistinguishable from similar specimens from GGU sample 271718 (Fig. 6; PMU 38324-38326); they are collectively placed within Stenothecoides terraglaciei, which is abundant in GGU sample 271718.

Etymology. - From the Latin, terra (land) and glacies (ice), meaning land of ice, with reference to Greenland.

Diagnosis. - Species of Stenothecoides with a prominent transverse tooth on the interior of the ventral valve. Juveniles bilaterally symmetrical, initially oval, but larger specimens are inequivalve and inequilateral, varying from elongate to leaf-shaped, often with a median extension of the anterior margin; they show slight clockwise to anticlockwise curvature of the articulated shell in dorsal view. External surface of thick shell ornamented with comarginal growth lines. Internal moulds of dorsal valve often with median carina and a frondose pattern of low ridges and channels that converges medially on the anterior margin. Internal lateral margins smooth, without corrugation of ridges and grooves perpendicular to the margin.

Description. - Articulated specimens are not known. The smallest observed juvenile ventral valves (internal moulds with length about $300 \mu \mathrm{m}$ ) are slightly longer than wide, but the preserved internal moulds of ventral and dorsal valves with a length of about $700 \mu \mathrm{m}$ are about twice as long as wide, with discernible slight coiling in plan view (Fig. 4E). The juvenile ventral valve is uniformly convex along its posterior-anterior profile, but the internal mould has a prominent groove beneath the apex reflecting a transverse tooth on the interior of the ventral valve (Fig. 5A, C-F, K; arrow in F). A raised rim lying to the posterior (adapical) of the groove is a mould of the channel surrounding the tooth on the valve interior (Fig. $5 \mathrm{G}-\mathrm{J})$. Internal moulds of juvenile dorsal valves lack the transverse groove. Even at sizes of about $700-800 \mu \mathrm{m}$, internal moulds of the dorsal valve have a relatively acute apex that overhangs the posterior margin, with a distinct sub-apical surface, whereas the posterior termination of moulds of the ventral interior is blunt and often truncated in appearance (compare arrowed surfaces of larger specimens in Fig. 4B, I).

Internal moulds of the dorsal valve in particular are often elongate, reflecting the raised, narrow, median portion of the valve (Fig. 4J, O) that is prominent at this growth stage, but this appearance may be greatly modified by incomplete phosphatization within the valve, as discussed above. In large specimens (Fig. 4K, O), the valves are leaf-shaped, widening towards the anterior margin, with width about two thirds of length. The anterior margin may be extended into a broad projecting lobe (Fig. 4H, K). Lateral areas of internal moulds are smooth, without ridges and sharp grooves perpendicular to the margin. Shell thick, particularly around the posterior where a shallow emargination may be present (Fig. $5 \mathrm{~N}$ ). Ornamentation only of comarginal growth lines, which may be slightly rugose (Fig. 4M).

Discussion. - The few available specimens of Stenothecoides cf. elongata from the contemporaneous GGU sample 271492 are elongate with ridges and sharp grooves on the limestone internal mould perpendicular to the lateral margin. These structures have not been observed in the numerous internal moulds of Stenothecoides terraglaciei available from GGU sample 271718. Indistinguishable internal moulds of juvenile ventral shells occur in both samples (Figs 5A-F, K; 6).

Silicified specimens of Stenothecoides elongata from the Wheeler Shale Formation (Miaolingian Series) of Utah, illustrated by Robison (1964) preserve an internal tooth, as does Stenothecoides terraglaciei, but have slender, elongate, oval, valves that are almost bilaterally 


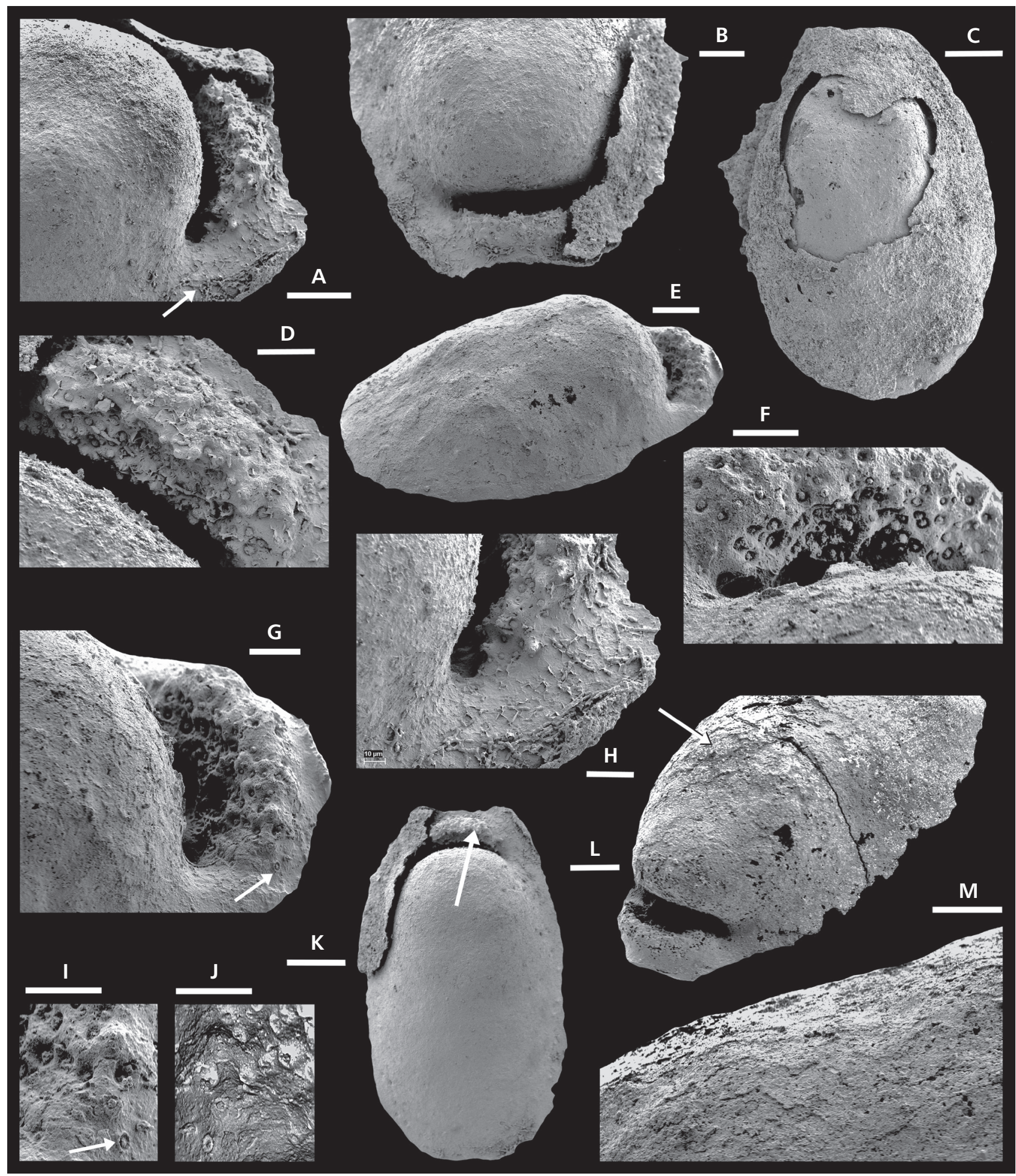

Figure 6. Internal moulds of juvenile Stenothecoides, Henson Gletscher Formation, Cambrian (Miaolingian Series, Wuliuan Stage), GGU sample 271718, Løndal (except L). A, B, D, H, K - PMU 38324, ventral surface with slot formed by transverse tooth and pedicle attachment scar (K, arrow); A - oblique lateral view with euendoliths on margin (arrow and detail in $\mathrm{H}$ ); B - oblique posterior view; D - detail of pedicle attachment scar. C - PMU 38325 , ventral view of internal mould and phosphatic external coating of the dissolved shell. E-G, I, J, M - PMU 38326 in oblique lateral view (E) with details of pedicle attachment scar (F, G, arrow in G showing location of I, J); I - detail of G with three zoned attachment point arrowed; J - digital cast of I showing relief of fibre attachment points as conical structures on interior surface of shell; $\mathrm{M}$ - oblique view of surface of internal mould showing obscure foliated structure. L - PMU 38327 from GGU sample 271492, Lauge Koch Land, oblique ventral view of internal mould showing obscure foliated structure. Scale bars: $100 \mu \mathrm{m}(\mathrm{C}, \mathrm{K}), 50 \mu \mathrm{m}$ (A, B, E, L), $20 \mu \mathrm{m}$ (D-J, M). 
symmetrical about the median line, as are several specimens figured by Rasetti $(1954,1957)$ from the upper Mount Whyte Formation (Wuliuan Stage) of British Columbia. However, Rasetti (1954) and Yochelson (1969) also illustrated a more asymmetric specimen with pronounced radial ridges and grooves on the internal mould not known from Stenothecoides terraglaciei.

Stenothecoides groenlandica was described by Peel (1988) from the Holm Dal Formation of western Peary Land (Miaolingian Series, Guzhangian Stage) on the basis of 15 isolated valves of varied form, but with the thick shell preserved (Fig. 1A, H). Comparison with Stenothecoides terraglaciei is hindered by the lack of information concerning interior structures, but the posterior of Stenothecoides terraglaciei is more strongly elevated, and the point of greatest transverse width is located closer to the anterior margin.

Koneva (1979b) described seven new species of Stenothecoides, which are morphologically very similar to each other, on the basis of isolated valves with external ornamentation from Cambrian Series 2 in Maly Karatau and Tamdytau, southern Kazakhstan and adjacent Uzbekistan. Most are almost bilaterally symmetrical and lack a median carina near the anterior, although the prominence of the posterior apex is similar to the much younger Stenothecoides terraglaciei. Koneva (1979b, pl. 5, fig.10) illustrated prominent ridges and separating channels on the lateral area of a partly exfoliated specimen of Stenothecoides proximus Koneva, 1979b, a structure known in Stenothecoides cf. elongata from GGU sample 271492, but not in Stenothecoides terraglaciei. Seven additional new species of Stenothecoides were described from Cambrian Series 2 of Kazakhstan by Koneva (1979a), together with specimens assigned to Stenothecoides elongata, Stenothecoides poulseni and Stenothecoides cf. labradorica.

It is likely that the many species of Stenothecoides described by Koneva (1979a, b) represent variation within a much smaller number of taxa. Most are known from isolated valves showing strong antero-posterior curvature, a well-developed posterior apex and prominent comarginal ornamentation. An articulated specimen of an elongate form, Stenothecoides bellus Koneva, 1979, the holotype of which is illustrated here (Fig. 1C), is similar to the articulated specimen collected by I.A. Sytchev from Altai Sayan, and figured by Yochelson (1969, fig. 1).

Stenothecoides knighti Yochelson, 1969, from Cambrian Series 2 of the Yukon, Canada, the articulated specimen illustrated by Yochelson (1969, fig. 2), has a more rounded posterior margin (anterior in the usage of Yochelson 1969) than Stenothecoides terraglaciei. Stenothecoides yochelsoni Yu, 1996, from the early Cambrian Tongying Formation of western Hubei, China, is a slender, slightly curved form described on the basis of a single articulated specimen, length $1.1 \mathrm{~mm}$. Yu (1996, fig. 2e, f) illustrated an articulated specimen in which the ventral valve is closely similar in shape to the ventral valve of Stenothecoides terraglaciei, with the dorsal valve projecting significantly beyond the posterior margin. Details of ornamentation and internal structures in Stenothecoides yochelsoni are not known.

\section{Stenothecoides cf. elongata (Walcott, 1884)}

Figure 7

1954 Stenothecoides cf. S. elongata. - Rasetti, p. 63, pl. 11, figs 6-10; pl. 12, figs 1-4.

1957 Stenothecoides cf. S. elongata. - Rasetti, p. 972, pl. 12, figs 1,2 .

1969 Stenothecoides cf. elongata. - Yochelson, p. 55, fig. $4 \mathrm{a}-\mathrm{c}$.

Material. - MGUH 33948 from GGU sample 271492, a limestone internal mould from Lauge Koch Land. Henson Gletscher Formation, Cambrian, Miaolingian Series, Wuliuan Stage, Ptychagnostus gibbus Biozone. Internal moulds of juvenile Stenothecoides from GGU sample 271492 cannot be distinguished morphologically from those in GGU sample 271718 that are referred to Stenothecoides terraglaciei; they are collectively referred to Stenothecoides terraglaciei.

Discussion. - This elongate, oval, internal mould shows slight clockwise curvature in plan view, with maximum width almost two thirds of length (Fig. 7A). The apex is protruberant and overhangs the posterior margin; a rounded carina is developed in the anterior half along the median line. Deep grooves are distributed along the lateral margins, curving towards the posterior, but absent from the anterior margin. They represent sharp ridges on the shell interior and are separated on the internal mould by broad rounded ridges of varying width. Traces of broad, rounded, ridges curve posteriorly in towards the median carina. Three circular scars are located on the median line near the apex (Fig. 7C, arrow). The ventral valve, with tooth if present, has not been seen.

In terms of the elongate form, overhanging apex and corrugations along the lateral margins of the internal mould, this specimen can be compared to Stenothecoides cf. elongata as illustrated by Rasetti (1954) from the upper Mount Whyte Formation (early Wuliuan Stage) of British Columbia, although the latter is more asymmetric. That specimen was re-illustrated by Yochelson (1969, fig. 4) although it should be noted that the illustration of the plan view presented by Yochelson $(1969$, fig. 4a) is reversed relative to that of Rassetti (1954, pl. 12, fig.2). Silicified stenothecoid valves illustrated by Johnston et al. (2017) and Johnston (2019) from the Yoho River 


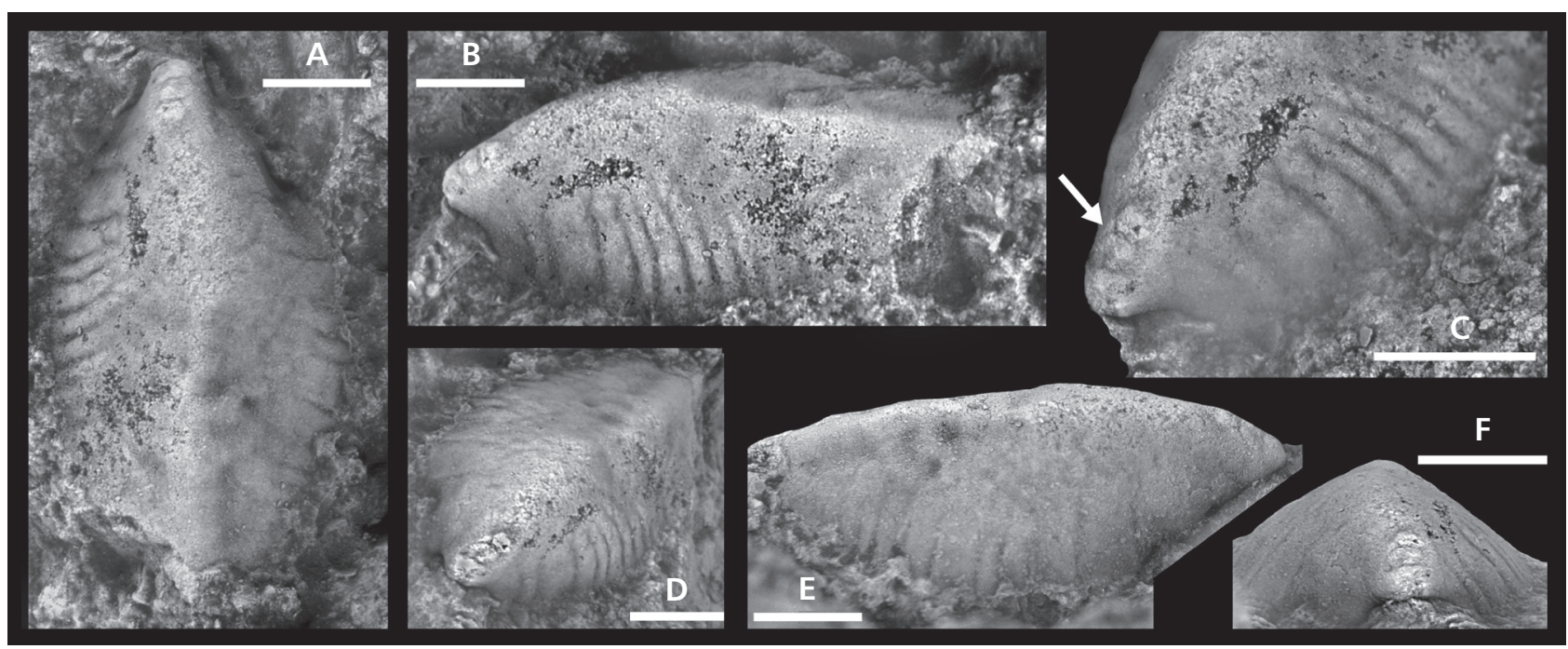

Figure 7. Stenothecoides cf. elongata (Walcott, 1884) MGUH 33948 from GGU sample 271492, internal mould of dorsal valve. Henson Gletscher Formation, Cambrian (Miaolingian Series, Wuliuan Stage), Lauge Koch Land. A - plan view; B - oblique lateral view; C - oblique posterior view of overhanging apex, with three circular scars, arrow; D, F - oblique posterior views; E - lateral view, with posterior to right. Scale bars: $1 \mathrm{~mm}$.

Limestone Member of the Burgess Shale Formation, British Columbia, display marginal corrugation similar to the Greenland specimen and a prominent posterior tooth resembling the posterior transverse tooth of specimens from GGU sample 271718 (Fig. 5G-J). Silicified, elongate, tooth-bearing specimens from the Wheeler Shale Formation of Utah described by Robison (1964) lack the internal corrugation.

\section{Genus Stenothecella Aksarina in Aksarina \& Pelman, 1978}

Type species. - Stenothecella sibirica Aksarina in Aksarina \& Pelman, 1978, lower Cambrian, (Cambrian Stage 4, Lenian Regional Stage), Kuznetskiy Alatau, Siberia.

\section{Stenothecella cf. sibirica Aksarina in Aksarina \& Pelman, 1978 \\ Figure 8}

Material. - MGUH 33949 from GGU sample 271492, a limestone internal mould from Lauge Koch Land, and a few incomplete phosphatized internal moulds (not illustrated) from GGU sample 271718, Løndal, Peary Land. Henson Gletscher Formation, Lauge Koch Land, Cambrian, Miaolingian Series, Wuliuan Stage, Ptychagnostus gibbus Biozone.

Discussion. - An articulated elongate specimen of Stenothecella sibirica Aksarina in Aksarina \& Pelman, 1978, with clockwise curvature (Aksarina \& Pelman, 1978, pl. 17, fig. 6), has a length of about $10 \mathrm{~mm}$. This is three times the size of MGUH 33949 (Fig. 8C, F), which is an internal mould of a dorsal valve. In plan view, the Greenland specimen is diamond-shaped, with only slight curvature visible at the posterior; its width is almost half of the total length and maximum width lies just anterior of mid-length (Fig. 8C). The posterior-anterior profile is uniformly convex, with the apex overhanging the posterior margin. In addition to the two series of about 20 pairs of muscle scars along the posterior axis (Fig. 8E), the anterolateral areas show weak comarginal growth corrugations (Fig. 8B). The fine radial grooves on the lateral surfaces (Fig. 8A, D) are not visible in the holotype from Siberia (Aksarina \& Pelman 1978, pl. 17, fig. 4).

Following the original record from Cambrian Stage 4 of Kuznetskiy Alatau (Aksarina \& Pelman 1978), Stenothecella sibirica was recorded from Cambrian Series 2 (Atdabanian and Botoman Regional Stages) in Mongolia (Esakova \& Zhegallo 1996). Korovnikov et al. (2018) reported Stenothecella sp. from the Usinskaya Formation (Atdabanian) of the Kiya River, Kuznetsk Alatau. Thus, Stenothecella cf. sibirica from the Henson Gletscher Formation (Wuliuan Stage, Ptychagnostus gibbus Biozone) is the youngest described representative of the genus.

\section{Morphology and ontogeny}

A variety of internal structures, summarized by Rozov (1984), has been described in stenothecoids, although the function of these remains obscure, thereby hindering placement of stenothecoids as a group. Interpretation is complicated by great variation in morphology within and between different assemblages, and also by different styles of preservation. The present material from the Henson Gletscher Formation lacks articulated specimens and information concerning external ornamentation of the type 
preserved in Stenothecoides groenlandica Peel, 1988, or most of the specimens illustrated by Koneva (1979a, b), is incomplete. However, the combination of internal moulds of two lithologies (limestone in GGU sample 271492, phosphate in GGU sample 271718) and partly exfoliated specimens facilitates morphological and ontogenetic interpretation of just these collections. Note that the applicability of these interpretations to other assemblages remains to be established.

Shell structure. - The phosphatized surfaces of internal moulds of Cambrian helcionelloid molluscs and Bivalvia often replicate shell structure from the interior surface of the calcareous shells (Runnegar 1985; Vendrasco et al. 2010, 2011a, b). Similar structures have not been recognized on the numerous internal moulds of mature Stenothecoides from GGU sample 271718, probably reflecting too poor preservation of the mould surface. Some juveniles, however, show traces of an imbricate foliate structure on the supra-apical surface of the internal mould (Fig. 6L, M) reminiscent of those illustrated by (Runnegar 1985; Vendrasco et al. 2010, 2011a, b). However, the innermost shell layer of some rhynchonelliformean brachiopods may also display a tabular form (Williams 1997).

\section{Ontogeny}

Numerous small, bilaterally symmetrical internal moulds of juvenile specimens collectively referred to Stenothecoides terraglaciei, length 300-600 $\mu \mathrm{m}$, from both GGU samples 271492 and 271718 , preserve the prominent tooth of the ventral valve as a deep, oblique, transverse slot on the surface of the internal mould (Figs 5A-F, K; $6 \mathrm{E}, \mathrm{I}, \mathrm{K}$ ). Posterior (adapical) to this tooth slot, a ridge on the internal mould (Figs 5F, 6K, arrows) represents the shallow channel that separates the tooth from the posterior valve margin (Fig. 5J). At its maximum extent, phosphatization may completely fill the valve, resulting in preservation of the valve margin as a flat surface posterior to this ridge (Figs 5A, 6K). In less completely infilled valves, the tooth slot may be a hole penetrating the preserved mould. In internal moulds of juvenile ventral valves in which the tooth slot is only partially preserved, the surface moulded against the inner (abapical) surface of the tooth (Fig. 5B, tilted towards the viewer) may resemble the internal mould of the sub-apical surface of the dorsal valve of larger specimens (Fig. 4C, D).

Initially, the juvenile ventral valve is oval in plan view but its supra-apical surface becomes proportionally longer with growth (Figs 5A-C, E; 6K). Patches of adherent phosphatized shell at the posterior indicate that the posterior-anterior profile is convex, without the develop- ment of an apex on the valve (Fig. 6C). However, larger specimens quickly develop a blunt apex on account of the rapid posterior thickening of the shell. The transverse profile of the internal mould is broadly convex, but may be slightly irregular, often with a slight median depression (Figs 5D, F; 6C). The tooth slot in the internal mould is oblique to the plane of commissure (Fig. 5F, arrow), but the tooth curves with growth to become almost perpendicular in the largest available specimen (Fig. 5G, H).

Internal moulds of juvenile dorsal valves are usually narrow (probably reflecting incomplete phosphatization along the lateral margins) and possess a distinct apex; indications of a tooth or socket corresponding to the tooth of the ventral valve tooth have not been recognized in the dorsal valve. The configuration of the conjoined ventral and dorsal valves likely resembled the articulated specimen of Stenothecoides yochelsoni Yu, 1996 from the lower Cambrian of China illustrated by Yu (1996, fig. 2e), although the apex of the dorsal valve is more prominent in that specimen.

The internal moulds of the juvenile ventral valves of the specimens from the Henson Gletscher Formation closely resemble internal moulds of Corystos thorntoniensis Vendrasco, Porter, Kouchinsky, Li \& Fernandez, 2010, originally described from the Gowers Formation (Miaolingian Series, Drumian Stage) of the Georgina Basin, Australia (Vendrasco et al. 2010). Vendrasco et al. (2010, p. 130) considered Corystos to have a unique form and placed it as 'Class incertae sedis'. The Greenland and Australian specimens are of similar size and oval shape in plan view, with a broadly rounded apex that is more inflated in Corystos. Beneath the apex, internal moulds of both taxa show a prominent transverse groove. The groove is thin and almost parallel to the margin in Corystos and the plate forming it was compared to the pegma of rostroconch molluscs by Vendrasco et al. (2010). In contrast, the transverse groove of internal moulds of juvenile Stenothecoides from the Henson Gletscher Formation is broader (anterior-posterior) and more steeply inclined, sometimes almost perpendicular to the plane of the margin (Figs 5A-E, F, K; 6A), reflecting the massive transverse posterior tooth on the interior of the ventral valve.

\section{External and internal corrugation}

External surfaces of both valves of Bagenovia sajanica Horný, 1957, the type species of Bagenovia, show a prominent, coarse, radial, corrugated ornamentation of alternating ridges and channels that appears to be present also on the internal moulds in partly exfoliated conjoined specimens figured by Sytchev (1960). The ridges and channels are perpendicular to the lateral margins but curve posteriorly (adapically) as the distinct carina forming the 


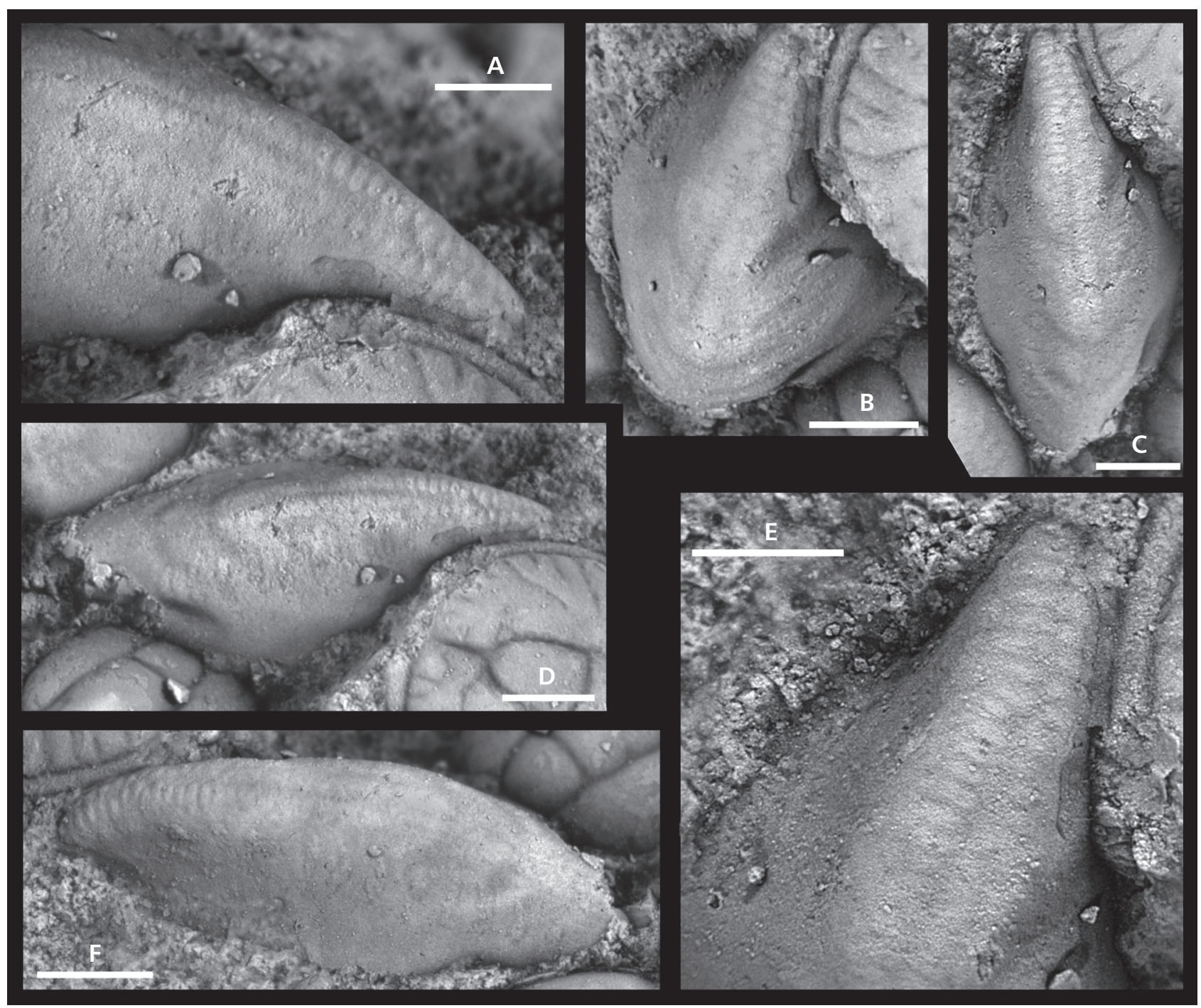

Figure 8. Stenothecella cf. sibirica Aksarina in Aksarina \& Pelman, 1978, MGUH 33949 from GGU sample 271492, internal mould of dorsal valve. Henson Gletscher Formation, Cambrian (Miaolingian Series,Wuliuan Stage), Lauge Koch Land. A - oblique lateral view; B - oblique anterior view; $\mathrm{C}$ - plan view; D, F - oblique lateral views; E - plan view of posterior median area showing paired scars. Scale bars: $1 \mathrm{~mm}(\mathrm{~B}), 700 \mu \mathrm{m}(\mathrm{C}, \mathrm{D}, \mathrm{F})$, $500 \mu \mathrm{m}(\mathrm{A}, \mathrm{E})$.

median line of each valve is approached, forming the fir-tree pattern of Koneva (1976), with the curvature of the corrugation being a reflection of slight allometric growth of the valves. Bagenovia kazakhstanica Koneva, 1976 shows a finer radial corrugation on the exterior than that present in the type species, and this fades towards the anterior margin (Fig. 1E). The prominent median carina of the type species is reduced or missing but may be expressed in the extension of the anterior margin into a broad lobe (Fig. 1E). Slightly irregular comarginal growth lines cover the entire external surface and dominate medially. External surfaces of some specimens of Bagenovia procera Koneva, 1976 from the lower Cambrian of Kazakhstan may show just comarginal growth lines (Fig. 1B, D, F), in which feature they compare closely with external surfaces of Stenothecoides (Figs 1C, 4M).
Internal moulds of Bagenovia also display numerous closely spaced radial ridges and grooves around their margins. Rozov (1984) considered these to reflect the corrugation of the outer shell surface, but the relationship between the two patterns is imprecise and appears to be coincidental (Fig. 1E). The grooves on the internal mould are deep and narrow, corresponding to sharply defined ridges on the shell interior, while the intervening ridges on the internal mould are broad and correspond to relatively wide channels on the shell interior (Fig. 1E, I, J). The grooves become more closely spaced and shallower anteriorly, and are absent from the median area of the anterior margin (Fig. 1K). Typically, the ridges and grooves are conspicuous in a restricted zone near to the margins but absent from central areas of the valve. 
In Bagenovia kazakhstanica (Fig. 1J) and Bagenovia procera (Fig. $1 \mathrm{~K}$ ) the central area of internal moulds is traversed by a small number of broad, shallow ridges and channels disposed symmetrically about the median line, but curving strongly towards the anterior margin as they approach the median line to form a frondose pattern. Thus, the overall frondose pattern on the internal mould is opposite to the fir-tree pattern of the ridges on the external surface. The broad, shallow ridges of the central area may appear as parallel rows of swellings located on either side of the longitudinal median depression on the internal mould (Fig. 1J), corresponding to shallow depressions on the shell interior.

External ornamentation of comarginal growth lines (Fig. 1A-C, E, G, H) is preserved on patches of shell adhering to internal moulds from GGU sample 271718 (Figs $4 \mathrm{M}, 5 \mathrm{M}$ ) or as weak comarginal corrugations on some internal moulds (Fig. 4F). Many internal moulds from the same sample (Fig. 4A, G, H, K, L, N, O) display the broad low ridges and wide grooves curving towards the anterior margin characteristic of the frondose pattern in the median area of Bagenovia kazakhstanica and Bagenovia procera (Fig. 1I-K), although a median carina is present in contrast to the shallow median depression in the illustrated specimen of Bagenovia kazakhstanica (Fig. 1J). As in Bagenovia (Fig. 1E, K), the anterior margin is extended medially in some of these Greenland specimens (Fig. 4H, K). The lateral margins in most of the phosphatized internal moulds from GGU sample 271718 are not preserved due to the restricted extent of phosphatization, but traces of the prominent marginal zone of ridges and grooves that characterize Bagenovia have not been seen in any of the numerous available specimens. Marginal ridges and grooves are also absent from the inner surface of ventral valves with preserved shell (Fig. $5 \mathrm{G}, \mathrm{H})$. In contrast, a marginal zone of flat-topped ridges and deep narrow grooves is well preserved on an elongate limestone internal mould from GGU sample 271492 referred to Stenothecoides cf. elongata (Fig. 7). The anterior curvature of the broad median frondose ridges in this specimen is just discernible near the anterior margin adjacent to the median carina (Fig. 7A).

\section{Ventral tooth}

Robison (1964) illustrated a single peg-like tooth within some silicified valves of Stenothecoides elongata from the Miaolingian Series (Drumian Stage) of Utah, noting a corresponding depression or socket on other valves. Similar tooth-bearing silicified specimens were illustrated by Johnston et al. (2017) and Johnston (2019) from the Yoho River Limestone Member of the Burgess Shale, British Columbia (Miaolingian Series). No evidence of a socket or shell surface opposing the tooth has been found in the abundant internal moulds from the Henson Gletscher Formation. However, it is possible that incomplete phosphatization of the shell interior may obscure the presence of a socket in dorsal valves (compare Fig. 3A, B). Johnston et al. (2017) noted uncertainty about the presence of a socket in silicified material from the Yoho River Member.

Specimens with a tooth are interpreted as ventral valves (Figs 3A; 5G-J; 6L, O) and the apex of the valve interpreted as dorsal extends beyond the posterior margin of the ventral valve, as illustrated by Yochelson (1969), Koneva (1979a, b) and Yu (1996). The lack of a socket suggests that the single ventral tooth does not form a direct mechanical hinge with an opposing shell structure within the dorsal valve, although this function could be achieved by muscle or ligament attachment between the ventral tooth and the inner surface of the dorsal valve. However, clearly defined, corresponding muscle attachment scars on internal moulds of dorsal valves have not been observed. Some mature specimens from GGU sample 271718 show irregular raised structures near the apex at the posterior of internal moulds of the dorsal valve (Fig. 4J, $\mathrm{O})$ but convincing evidence that these might represent muscle scars is lacking. A specimen of Stenothecoides $\mathrm{cf}$. elongata from GGU sample 271492 shows three raised, circular scars, separated by transverse grooves, along the median crest near the apex that might represent muscle attachment sites corresponding to the tooth in the ventral valve (Fig. 7A-C). However, evidence of an internal tooth in GGU sample 271492 is restricted to internal moulds of juvenile specimens of ventral valves (Fig. 5A-F, K). These juveniles are indistinguishable from specimens in GGU sample 271718 described as Stenothecoides terraglaciei sp. nov. They are identified as such herein, although their morphology may be characteristic of both species.

A fibrous structure near the apex of the ventral valve of juvenile specimens is interpreted as the attachment scar of a pedicle, discussed below. Fibres are rooted in the adapical wall of the tooth and the area immediately posterior to it (Fig. 6), indicating that the primary function of the tooth in the ventral valve of Stenothecoides is for attachment of the pedicle.

While it is assumed from available material that the posterior margins of both valves were juxtaposed (Fig. $3 \mathrm{~A}$ ), the transverse extension of the ventral tooth could suggest that it articulated with the subapical margin of the dorsal valve, an area not preserved in the available disarticulated material, but this would probably place the channel lying posterior and lateral to the tooth (Fig. $5 \mathrm{G}-\mathrm{J}$ ) just outside (posterior) of the hinge. Alternatively, the channel may have functioned as a socket for flanges developed on the raised posterior margin of the dorsal valve, similar to the marginal teeth described on each 
lateral valve margin at the posterior in Cambridium dentatum Pelman, 1985 and Dignus carinatus Pelman, 1985 from Cambrian Series 2 (Botoman Regional Stage) of Mongolia (Pelman 1985), but evidence of the presence of such flanges in the Greenland material has not been seen. The lateral teeth on the valve margins in Cambridium dentatum and Dignus carinatus are unlike the central transverse tooth of the Greenland specimens, and seem better suited for articulation between the valves. Lying to each side of the apex, they show similarity in their position to the dentition of Bivalvia and Tuarangiida (Peel 2021b).

\section{Pedicle attachment}

All examined internal moulds of ventral valves of juvenile Stenothecoides from GGU samples 271492 and 271718 display a prominent transverse swelling immediately posterior of the deep transverse channel formed by the tooth (Figs 5A, E; 6A, B, D-K). The swelling corresponds to the median part of the channel that delimits the posterior margin of the tooth on the shell interior (Fig. $5 \mathrm{G}-\mathrm{K}, \mathrm{L}, \mathrm{O}$ ) and its anterior (abapical) face is a mould of the posterior face of the transverse tooth. The swelling is covered with tubercles and pits that in detail represent preservational variants of a sub-cylindrical structure with a solid core (Fig. 6F, I), about $4 \mu \mathrm{m}$ in diameter. Typically, the structures have an outer wall, usually preserved in negative relief on the internal mould that surrounds an inner core. In terms of the surface of the shell interior, the outer wall has positive relief and surrounds an inner cavity (Fig. 6F, G, I), the overall structure being conical and rising from the posterior face of the transverse tooth (Fig. 6J, a digital cast of 6I). Three concentric zones are present in a few specimens (Fig. 6I, arrow).

The shape of the conical structures suggests interpretation as epibiont holdfasts, and small pits of similar shape may be scattered across the surface of some specimens. However, their presence in all examined specimens where they dominate in just a restricted location within the valve interior argues against this interpretation. In some specimens, adjacent areas of the valve brim show infilled burrows of euendoliths (Fig 6H, located by arrow in 6A) that are only about $2 \mu \mathrm{m}$ in diameter, but these represent galleries excavated within the shell and are clearly unrelated to the conical structures in the posterior area.

Pits on internal moulds of Bagenovia were described by Koneva (1979a) and Rozov (1984) but these are arranged in transverse rows within the frondose pattern, on either side of the median plane, in a pattern quite unlike the posterior cluster of pits in Stenothecoides terraglaciei.

The apical (posterior) location of the tuberculose and pitted zone might suggest that the structure is the attachment scar of a ligament joining the two valves, but no indication of a corresponding structure has been found on the dorsal valve. There is little to suggest functional or morphological similarity with the ligament of Bivalvia (Trueman 1969, Waller 1998).

The consistent and precise location of the conical structures promotes their interpretation as the attachment points of a suite of fibres that anchored the juvenile Stenothecoides to the substrate (Fig. 9). It is not known if the fibres were separate or joined together to form a more robust pedicle-like structure, but the apparent lack of a well-developed emargination at the posterior margin of juveniles may suggest the former.

Some larger ventral valves from GGU sample 271718, with patches of preserved shell, show a shallow median emargination in the posterior margin (Fig. $5 \mathrm{~N}, \mathrm{O}$ ). A similar structure has been described by Johnston et al. (2017) in Stenothecoides from the Miaolingian of British Columbia, and was interpreted as a possible rudimentary pedicle foramen. A subapical emargination in the posterior margin seems to be present in the holotype of Bagenovia procera Koneva, 1976, from the lower Cambrian of Kazakhstan, and was also illustrated by Pelman (1985) in Katunioides akbashinensis Pelman, 1985 from Cambrian Series 2 (Botoman Regional Stage) of Mongolia. While evidence of the attachment points of individual fibres has not been observed on the shell interior of these larger specimens, the interpretation of the described attachment points in juveniles strongly supports the conclusion that a pedicle was present.

Pedicle-like attachment structures are best known in brachiopods but they have been reported in several different organisms [Holmer \& Caron 2006, Holmer et al. 2008, Zhang et al. 2014, Sun et al. 2018 (but see Liu et al. 2020)]. Brachiopod pedicles are complex and varied organs (Williams et al. 1997) and there is little basis for direct morphological comparison with the postulated attachment structure in stenothecoids, other than the presence of fibres in the pedicle of rhynchonelliformean brachiopods. Fibres in brachiopod pedicles form a stiff outer zone within the

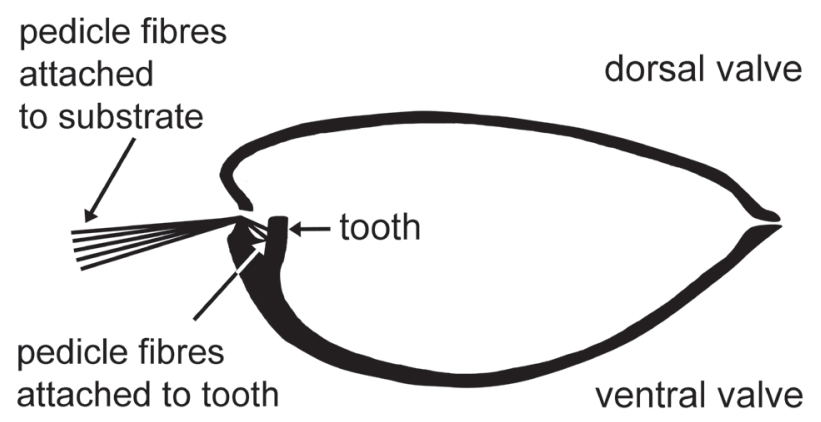

Figure 9. Schematic cross-section through Stenothecoides showing pedicle. 
cylindrical pedicle and in extant rhynchonelliformeans they are individually up to ten times the diameter of the postulated fibres in Stenothecoides. The fibrous pedicle is attached by muscles to the shell interior of the brachiopod, rather than directly by the fibres, enabling control of its orientation (Richardson 1979, Williams et al. 1997). Its fibrous structure is clearly demonstrated in the fossil record by the external attachment of the pedicle to the substrate, rather than in the point of origin of the fibres seen here in Stenothecoides. Individual fibres in the pedicle of most rhynchonelliformeans are etched into the substrate surface and produce a distinctive trace fossil, Podichnus Bromley \& Surlyk, 1973, known as early as the Ordovician (Bromley \& Surlyk 1973, Robinson \& Lee 2008, Santos et al. 2014).

\section{Muscle scars in Stenothecella}

A well-preserved limestone internal mould from GGU sample 271492 preserves about 20 pairs of raised elliptical scars along the posterior median line of a dorsal valve (Fig. 7). The small scars, representing depressions in the inner surface of the shell, are slightly irregular in form and lie on each side of a narrow median groove that has a weakly zig-zag form. They occur along about two thirds of the length of the valve, becoming increasingly obscure towards the anterior (Fig. 8D). A zone of fine radial groves lies on each lateral surface about half way between the median crest and the lateral margins (Fig. 8A, D, F). Similar, but less well preserved patterns occur in several phosphatized internal moulds from GGU sample 271718.

A similar pattern of median scars interpreted as a loop of muscular imprints was described in Stenothecella sibirica Aksarina in Aksarina \& Pelman, 1978 from the lower Cambrian of Kuznetskiy Alatau, Siberia (Aksarina \& Pelman 1978), which in external form and ornamentation is very close to Stenothecoides. Rozov (1984, fig. 7) tentatively interpreted the pattern as formed by intestinal loops. Rozanov \& Zhuravlev (1992) compared this pattern to the intestinal loops of orthothecid hyoliths, as described subsequently in detail by Devaere et al. (2014) from the Terreneuvian of the south of France, but the interpretation as a continuous, looped, intestine is not convincing, on the basis of the original illustrations (Aksarina \& Pelman 1978, pl. 17, figs 4-6). The median scars are tentatively interpreted as muscle scars, although their function is not known; they may well be associated with attachment of a digestive or respiratory tract but find no obvious equivalence in brachiopods or molluscs. Their location on the median line may suggest that they are associated with the axis of the frondose structure on internal moulds of Bagenovia (Fig. 1J, K).
Pits on the internal mould of Marakaria polygonalis Aksarina, 1968 from Kuznetskiy Alatau (Cambrian Series 2) were interpreted by Rozov (1984) as muscle scars, but the scars in Stenothecella cf. sibirica are more numerous and raised on the surface of the internal mould. Sargaella mirtovi Aksarina in Aksarina \& Pelman, 1978 from Kuznetskiy Alatau also shows series of scars along the median line (Aksarina \& Pelman 1978, Rozov 1984).

Dorsal arrays of shell-attachment muscle scars with a comarginal distribution are well known in tryblidiid monoplacophorans (Lindström 1884, Horný 1963, Peel 1977) and other cap-shaped Palaeozoic shells (Dzik 2010). The scars in Stenothecella cf. sibirica differ in their location close to the median line.

\section{Conclusions}

Study of phosphatized internal moulds of stenothecoids from the Henson Gletscher Formation (Miaolingian Series, Wuliuan Stage) of North Greenland increases insight into the morphological variation of a problematic Cambrian group mainly known from silicified replicas and limestone specimens. These compositional differences emphasize the need for an integrated approach across preservational boundaries to resolve the relationship of stenothecoids, not least as regards interpretation of the variety of internal structures.

Stenothecoides terraglaciei $\mathrm{sp}$. nov. was attached to the substrate by a fibrous pedicle emerging between the valves at their posterior margin. The posterior (adapical) surface of the prominent transverse tooth within the ventral valve formed the internal attachment site of individual fibres comprising the pedicle. The presence of a pedicle strongly suggests a closer relationship of stenothecoids to the brachiopod stem than to molluscs, but formulation of such a step is premature, awaiting an integrated interpretation of the internal structures preserved on internal moulds.

\section{Acknowledgements}

Samples were collected during the North Greenland Project (1978-80) of the Geological Survey of Greenland, Copenhagen, with the assistance of Peter Frykman (Copenhagen). Svetlana Koneva (Alma Ata) provided access to her stenothecoid collections during a visit to Uppsala in 1994. Some SEM images were made by Artem Kouchinsky during 2011 at the Swedish Museum of Natural History, Stockholm. Michael Streng (Uppsala) is thanked for ongoing discussions concerning stenothecoids and guidance with scanning electron microscopy. I am grateful to Jerzy Dzik (Warsaw) and Michael J. Vendrasco (Pasadena) for comments concerning the submitted manuscript, and to Jan-Ove R. Ebbestad (Uppsala) and Arden Roy Bashforth (Copenhagen) for help with the curation of figured specimens. 


\section{References}

Aksarina, N.A. 1968. Probivalvia - a new class of ancient molluscs, 77-86. Novye dannye po geologii i poleznym iskopaemym zapadnoi Sibiri 3, 77-86. [in Russian]

Aksarina, N.A. \& Pelman, Yu.L. 1978. Cambrian brachiopods and bivalve molluscs of Siberia. Trudy Akademiya Nauk SSSR, Sibirskoy otdelenie 362, 1-178. [in Russian]

Bengtson, S. 2004. Early skeletal fossils, 67-77. In LipPs, J.H. \& WagGoner, B.M. (eds) Neoproterozoic-Cambrian biological revolutions. The Paleontological Society Papers 10.

Bengtson, S., Conway Morris, S., Cooper, B.J., Jell, P.A. \& RunNegar, B.N. 1990. Early Cambrian fossils from South Australia. Memoirs of the Association of Australasian Palaeontologists 9, 1-364.

Blaker, M.R. \& PeEL, J.S. 1997. Lower Cambrian trilobites from North Greenland. Meddelelser om Grønland, Geoscience 35, $1-145$.

Bouchet, P., Rocroi, J.-P., Hausdorf, B., Kaim, A., Kano, Y., Nützel, A., Parkhaev, P., Schrödl, M. \& Strong, E.E. 2017. Revised classification, nomenclator and typification of gastropod and monoplacophoran families. Malacologia 61, 1-526. DOI 10.4002/040.061.0201

Briggs, D.E.G., ERwin, D.H. \& Collier, F.J. 1994. The fossils of the Burgess Shale. 238 pp. Smithsonian Institution, Washington DC.

Bromley, R.G. \& SurLyk, F. 1973. Borings produced by brachiopod pedicles, fossil and Recent. Lethaia 6, 349-365. DOI 10.1111/j.1502-3931.1973.tb01203.x

Clausen, S. \& Peel, J.S. 2012. Middle Cambrian echinoderm remains from the Henson Gletcher Formation of North Greenland. GFF 134, 173-200.

DOI 10.1080/11035897.2012.721003

Devaere, L., Clausen, S., Álvaro, J.J., Peel, J.S. \& Vachard, D. 2014. Terreneuvian orthothecid (Hyolitha) digestive tracts from Northern Montagne Noire, France; taphonomic, ontogenetic and phylogenetic implications. PLoS ONE 9(2), e88583. DOI10.1371/journal.pone.0088583

DzIK, J. 2010. Brachiopod identity of the alleged monoplacophoran ancestors of cephalopods. Malacologia 52, 97-113. DOI 10.4002/040.052.0107

Elicki, O. \& Gürsu, S. 2009. First record of Pojetaia runnegari Jell, 1980 and Fordilla Barrande, 1881 from the Middle East (Taurus Mountains, Turkey) and critical review of Cambrian bivalves. Paläontolologische Zeitschrift 83, 267-291. DOI 10.1007/s12542-009-0021-9

Esakova, N.V. \& Zhegallo, E.A. 1996. Biostratigraphy and fauna of the Lower Cambrian of Mongolia. Trudy Sovmestnoj Sovetsko-Mongol'skoj Paleontologischeskoj Ehkspeditsii 46, 1-216. [in Russian]

Geyer, G. \& Peel, J.S. 2011. The Henson Gletscher Formation, North Greenland, and its bearing on the global Cambrian Series 2-Series 3 boundary. Bulletin of Geosciences 86, 465-534. DOI 10.3140/bull.geosci.1252

Hicks, H. 1872. On some undescribed fossils from the Menevian Group of Wales. Quarterly Journal of the Geological Society of London 27, 41-42.

DOI 10.1144/GSL.JGS.1872.028.01-02.17
Higgins, A.K., Ineson, J.R., Peel, J.S., Surlyk, F. \& SønderHOLM, M. 1991. Lower Palaeozoic Franklinian Basin of North Greenland. Grønlands Geologiske Undersøgelse Bulletin 160, 71-139. DOI 10.34194/bullggu.v160.6714

Hinz-SchallReuter, I. 1993. Cambrian ostracodes mainly from Baltica and Morocco. Archiv für Geschiebekunde 1, 385-448.

Holmer, L.E. \& CAron, J.-B. 2006. A spinose stem group brachiopod with pedicle from the Middle Cambrian Burgess Shale. Acta Zoologica 87, 273-290.

DOI 10.1111/j.1463-6395.2006.00241.x

Holmer, L.E., Skovsted, C.B., Brock, G.A., Valentine, J.L. \& Paterson, J.R. 2008. The Early Cambrian tommotiid Micrina, a sessile bivalved stem group brachiopod. Biology Letters 1, 724-728. DOI 10.1098/rsbl.2008.0277

HornÝ, R.J. 1957. Problematic molluscs (?Amphineura) from the Lower Cambrian of southern and eastern Siberia (U.S.S.R.). Sbornik Ústředního Ústavu Geologického, oddil paleontologický 23, 397-432.

HornÝ, R.J. 1963. Lower Paleozoic Monoplacophora and patellid Gastropoda (Mollusca) of Bohemia. Sborník Ústředního Ústavu Geologického, oddil paleontologický 28, 7-84.

Hou, X., Siveter, D.J., Siveter, D.J., Aldridge, R.J., Cong, P., Gabbott, S.E., Ma, X., Purnell, M.A. \& Williams, M. 2017. The Cambrian fossils of Chengjiang, China: The flowering of early animal life. $2^{\text {nd }}$ edition. 316 pp. Wiley, Oxford. DOI 10.1002/9781118896372

Ineson, J.R. \& Peel, J.S. 1997. Cambrian shelf stratigraphy of North Greenland. Geology of Greenland Survey Bulletin 173, 1-120. DOI 10.34194/ggub.v173.5024

JELL, P.A. 1980. Earliest known bivalve on Earth-A new Early Cambrian genus from South Australia. Alcheringa 4, 233-239. DOI 10.1080/03115518008618934

JoHnston, P.A. 2019. Morphology and relationships of Cambrian Stenothecoida. Geological Society of Hubei, Academic exchanges, Academic reports, online presentation. http:// www.hbsdzxh.com.cn/html/dzxh/news/2019/06/10/190610143 95911700001.html

Johnston, P.A., Streng, M. \& Virmani, N. 2017. New observations on the enigmatic Cambrian Stenothecoida. Abstract $26^{\text {th }}$ Canadian Paleontology Conference, Calgary, Proceedings 14, 18.

Koneva, S.P. 1976. New members of the Class Stenothecoida from the Lower Cambrian of central Kazakhstan. Paleontogical Journal 2, 230-233.

Koneva, S.P. 1979a. Stenothecoids and inarticulate brachiopods of the Lower Cambrian and basal Middle Cambrian of central Kazakhstan. Trudy Geologii Instituta, Akademiya Nauk SSSR, Kazakhstanskoy otdelenie, 1-123. [in Russian]

KonEva, S.P. 1979b. Cambrian stenothecoids from Maly Karatau and Tamdytia. Paleontologicheskiy Zhurnal 1, 44-51. [in Russian]

Korovnikov, I.V., Novozhilova, N.V. \& Tokarev, D.A. 2018. Distribution of Atdabanian (Early Cambrian) trilobites, archaeocyaths, and Small Shelly Fossils in the Altai-Sayan Folded Area. Paleontological Journal 52, 1481-1493. DOI 10.1134/S0031030118130075

Kouchinsky A.V. 2000. Mollusks, hyoliths, stenothecoids, and coeloscleritophorans, 326-349. In Zhuravlev, A.Yu. 
\& Riding, R. (eds) The ecology of the Cambrian radiation. Columbia University Press, New York, NY.

DOI 10.7312/zhur10612-015

Li, G., Zhang, Z., Hua, H. \& Yang, H. 2014. Occurrence of the enigmatic bivalved fossil Apistoconcha in the Lower Cambrian of Southeast Shaanxi, North China Platform. Journal of Paleontology 88, 359-366. DOI 10.1666/13-078

LindströM, G. 1884. On the Silurian Gastropoda and Pteropoda of Gotland. Kungliga Svenska Vetenskaps Akademiens Handlingar 19, 1-250. DOI 10.5962/bhl.title.11879

Liu, F., Skovsted, C.B., Topper, T.P., Zhang, Z. \& Shu, D. 2020. Are hyoliths Palaeozoic lophophorates? National Science Review 7, 453-469. DOI 10.1093/nsr/nwz161

MaAs, A., WaloszeK, D. \& Müller, K.J. 2003. Morphology, ontogeny and phylogeny of the Phosphatocopina (Crustacea) from the Upper Cambrian "Orsten" of Sweden. Fossils and Strata 49, 1-238.

McMenamin, M.A.S. 2020. Bradoriids (Arthropoda) and the Cambrian diversification. Geosciences 10, 119. DOI 10.3390/geosciences10040119

Palmer, A.R. 1954. An appraisal of the Great Basin Middle Cambrian trilobites described before 1900. United States Geological Survey Professional Paper 264-D, 53-86. DOI 10.3133/pp264D

Parkhaev, P.Yu. 1998. Siphonoconcha - a new class of Early Cambrian bivalved organisms. Paleontological Journal 32, $1-15$.

Peel, J.S. 1977. Relationship and internal structure of a new Pilina (Monoplacophora) from the late Ordovician of Oklahoma. Journal of Paleontology 51, 116-122.

Peel, J.S. 1988. Molluscs of the Holm Dal Formation (late Middle Cambrian), central North Greenland. Meddelelser om Grønland, Geoscience 20, 145-168.

Peel, J.S. 2021a. An outer shelf shelly fauna from Cambrian Series 2 (Stage 4) of North Greenland (Laurentia). Journal of Paleontology 95, Memoir 83, 1-41.

DOI 10.1017/jpa.2020.112

Peel, J.S. 2021b. Pseudomyona from the Cambrian of North Greenland (Laurentia) and the early evolution of bivalved molluscs. Bulletin of Geosciences 96, 195-215.

DOI 10.3140/bull.geosci.1827

Peel, J.S., Streng, M., Geyer, G., Kouchinsky, A. \& Skovsted, C.B. 2016. Ovatoryctocara granulata assemblage (Cambrian Series 2-Series 3 boundary) of Løndal, North Greenland. Australasian Palaeontological Memoirs 49, 241-282.

Pelman, Yu.L. 1976. Early-Middle Cambrian stentothecoids and new skeletal remains of unclear systematic position of ther stratigraphic district of Aldan and Lena. Trudy Instituta geologii i geofiziki, Akademiya Nauk SSSR, Sibirskoy otdelenie 296, 176-179.

Pelman, Yu.L. 1985. New stenothecoids from the Lower Cambrian of western Mongolia. Trudy Instituta geologii i geofiziki, Akademiya Nauk SSSR, Sibirskoy otdelenie 632,103-114.

Pojeta, J., JR \& Runnegar, B. 1976. The paleontology of rostroconch mollusks and the early history of the phylum Mollusca. United States Geological Survey Professional Paper 968, 1-88. DOI 10.3133/pp968
Ponder, W.F., Lindberg, D.R. \& Ponder, J.M. 2020. Biology and evolution of the Mollusca, Volume 2.870 pp. CRC Press, Boca Raton, Florida. DOI 10.1201/9781351115254

Poulsen, C. 1932. The Lower Cambrian faunas of east Greenland. Meddelelser om Grønland 87(6), 1-66.

Radugin, K.V. 1937. On the relations of the Cambrian and Precambrian in the Gornaya Shoria. Problems in Soviet Geology 7 , 295-317. [in Russian]

Rasetti, F. 1954. Internal shell structures in the Middle Cambrian gastropod Scenella and the problematic genus Stenothecoides. Journal of Paleontology 28, 59-66.

RasetTi, F. 1957. Additional fossils from the Middle Cambrian Mt. Whyte Formation of the Canadian Rocky Mountains. Journal of Paleontology 31, 955-972.

REsSER, C.E. 1938. Fourth contribution to nomenclature of Cambrian fossils. Smithsonian Miscellaneous Collections 97(10), $1-43$.

Richardson, J.R. 1979. Pedicle structure of articulate brachiopods, Journal of the Royal Society of New Zealand 9, 415-436. DOI 10.1080/03036758.1979.10421830

Robinson, J.H. \& LeE, D.E. 2008. Brachiopod pedicle traces: recognition of three separate types of trace and redefinition of Podichnus centrifugalis Bromley \& Surlyk, 1973. Fossils and Strata 54, 219-225.

Robison, R.A. 1964. Late Middle Cambrian faunas from western Utah. Journal of Paleontology 38, 510-566.

Robison, R.A. 1994. Agnostoid trilobites from the Henson Gletscher and Kap Stanton formations (Middle Cambrian), North Greenland. Bulletin Grønlands Geologiske Undersøgelse 169, 25-77.

DOI 10.34194/bullggu.v169.6726

Rozanov, A.Yu. \& Zhuravlev, A.Yu. 1992. The Lower Cambrian fossil record of the Soviet Union, 205-282. In LIPPS, J.H. \& Signor, P.W. (eds) Origin and early evolution of the Metazoa. Plenum Press, New York.

DOI 10.1007/978-1-4899-2427-8_7

Rozov, S.N. 1984. Stenothecoids morphology, terminology and systematical position, Trudy Instituta geologii i geofiziki, Akademiya Nauk SSSR, Sibirskoy otdelenie 597, 117-133. [in Russian]

RunNEGAR, B. 1985. Shell microstructures of Cambrian molluscs replicated by phosphate. Alcheringa 9, 245-257. DOI 10.1080/03115518508618971

Santos, A., Mayoral, E., Villas, E., Herrera, Z. \& Ortega, G. 2014. First record of Podichnus in orthide brachiopods from the Lower Ordovician (Tremadocian) of NW Argentina and its relation to the early use of an ethological strategy. Palaeogeography, Palaeoclimatology, Palaeoecology 399, 67-77. DOI 10.1016/j.palaeo.2014.02.003

Skovsted, C.B. 2006. Small shelly fauna from the upper Lower Cambrian Bastion and Ella Island Formations, North-East Greenland. Journal of Paleontology 80, 1087-1112. DOI 10.1666/0022-3360(2006)80[1087:SSFFTU]2.0.CO;2

Sun, H., Sмith, M.R., Zeng, H., ZhaO, F., Li, G. \& Zhu, M. 2018. Hyoliths with pedicles illuminate the origin of the brachiopod body plan. Proceedings of the Royal Society $B$ 285, 20181780. DOI 10.1098/rspb.2018.1780 
Sytchev, I.A. 1960. Phylum Mollusca: Mollusks, Class Lamellibranchiata; pelecypods, Paleozoic biostratigraphy of the Sayano-Altai Mountain region, vol. 1, Lower Paleozoic. Trudy SNIGGIMS 19, 253-256 [in Russian]

Trueman, E.R. 1969. Ligament, 58-64. In Moore, R.C. \& TeICHERT, C. (eds) Treatise on invertebrate paleontology, Part N, Mollusca 6, Bivalvia, Volume 1. Geological Society of America and University of Kansas, Boulder and Lawrence.

Vendrasco, M.J., Porter, S.M., Kouchinsky, A., Li, G. \& Fernandez, C.Z. 2010. New data on molluscs and their shell microstructures from the Middle Cambrian Gowers Formation, Australia. Palaeontology 53, 97-135. DOI 10.1111/j.1475-4983.2009.00922.x

Vendrasco, M.J., Chech, A.G. \& Kouchinsky, A.V. 2011a. Shell microstructure of the early clam Pojetaia and the independent origin of nacre within the Mollusca. Palaeontology 54, 825-850. DOI 10.1111/j.1475-4983.2011.01056.x

Vendrasco, M.J., Kouchinsky, A.V., Porter, S.M. \& Fernandez, C.Z. 2011b. Phylogeny and escalation in Mellopegma and other Cambrian molluscs. Palaeontologia Electronica 14, $1-44$.

Voronin, Yu.I., Voronova, L.G., Grigoreva, N.V., Drozdova, N.A., Zhegallo, E.A., Zhuravlev, A.Yu., Ragozina, A.L., Rozanov, A.Yu., Sayutina, T.A., Sysoev, V.A. \& Fonin, V.D. 1982. The Precambrian-Cambrian boundary in the geosynclinal areas (the reference section of SalanyGol, MPR). Trudy Sovmestnoj sovetsko-mongol'skoj paleontologischeskoj ekspedicii 18.150 pp. Nauka, Moscow. [in Russian]

Walcott, C.D. 1884. Paleontology of the Eureka District. United States Geological Survey Monograph 8, 1-298. DOI 10.5962/bhl.title. 23478

WALLER, T.R. 1998. Origin of the molluscan Class Bivalvia and a phylogeny of major groups, 1-45. In Johnston, P.A. \& Haggart, J.W. (eds) Bivalves: An eon of evolution: Paleobiological studies honouring Norman D. Newell. University of Calgary Press, Calgary.
Williams, A. 1997. Shell structure, 267-320. In Kaesler, R.L. (ed.) Treatise on invertebrate paleontology, Part H, Brachiopoda, Revised, Volume 1: Introduction. Geological Society of America and University of Kansas, Boulder and Lawrence.

Williams, A., James, M.A., Emig, C.C., Mackay, S. \& Rhodes, M.C. 1997. Pedicle, 60-69. In Kaesler, R.L. (ed.) Treatise on invertebrate paleontology, Part H, Brachiopoda, Revised, Volume 1: Introduction. Geological Society of America and University of Kansas, Boulder and Lawrence.

Williams, M., Siveter, D.J., Popov, L.E. \& Vannier, J.C. 2007. Biogeography and affinities of the bradoriid arthropods: Cosmopolitan microbenthos of the Cambrian seas. Palaeogeography, Palaeoclimatology, Palaeoecology 248, 202-232. DOI 10.1016/j.palaeo.2006.12.004

Yochelson, E.L. 1968 Stenothecoida, a proposed new class of Cambrian Mollusca. Abstracts International Palaeontological Union, Prague, Czechoslovakia, August 20-27, 1968, 34.

Yochelson, E.L. 1969. Stenothecoida, a proposed new class of Cambrian Mollusca. Lethaia 2, 49-62. DOI 10.1111/j.1502-3931.1969.tb01250.x

Yu, W. 1996. Early Cambrian stenothecoid molluscs from China. Records of the Western Australia Museum 18, 209-217.

Zhang, X.-G. 2007. Phosphatized bradoriids (Arthropoda) from the Cambrian of China. Palaeontographica, Abteilung A 281, 93-173. DOI 10.1127/pala/281/2007/93

Zhang, Z.-F, Li, G.-X., Holmer, L.E., Brock, G.A., Balthasar, U., Skovsted, C.B., Fu, D.-J., Zhang, X.-L., Wang, H.-Z., Butler, A., Zhang, Z.-L., CaO, C.-Q., Han, J., Liu, J.-N. \& SHu, D. 2014. An early Cambrian agglutinated tubular lophophorate with brachiopod characters. Scientific Reports 4, 4682. DOI 10.1038/srep04682

Zhuravlev, A.Yu. 2015. The early history of the Metazoa a paleontologist's viewpoint. Biology Bulletin Reviews 5(5), 414-461. DOI 10.1134/S2079086415050084 